\title{
Addressing Organisational Pressures as Drivers towards Sustainability in Manufacturing Projects and Project Management Methodologies
}

\author{
Fotios Misopoulos ${ }^{1}$, Roula Michaelides ${ }^{1, *}$, Mohammad Afiq Salehuddin ${ }^{1}$, Vicky Manthou ${ }^{2}$ \\ and Zenon Michaelides ${ }^{1}$ \\ 1 Management School, University of Liverpool, Liverpool L69 7ZH, UK; f.misopoulos@liverpool.ac.uk (F.M.); \\ M.Salehuddin@liverpool.ac.uk (M.A.S.); zenonm@liverpool.ac.uk (Z.M.) \\ 2 Department of Applied Informatics, University of Macedonia, 54636 Thessaloniki, Greece; \\ manthou@uom.edu.gr \\ * Correspondence: roulam@liverpool.ac.uk
}

Received: 9 April 2018; Accepted: 12 June 2018; Published: 20 June 2018

\begin{abstract}
The concept of sustainability continues to rapidly grow in interest from disparate academic and industrial fields. This research aims to elucidate further the implications of the sustainability drivers upon project management methodological approaches specifically in the manufacturing industry. This paper studies the three prevalent dialogues in the field of sustainability, relevant to the environmental and social aspects of the Triple Bottom Line, and utilises Institutional Theory to propose organisational pressures as affecting sustainability efforts in industrial manufacturing project management. Furthermore, the literature bodies of Lean and Life Cycle Analysis in manufacturing project management guided our reflection that the various drivers of sustainability put forward that do not consider the distinctive organisational pressures fail to address institutional and systemic project management issues holistically. The authors further conduct and draw on a systematic literature review on the constructs of sustainability in the manufacturing industry and their adopted methodologies, evaluating academic articles published from the year 2001 to 2017. The findings indicate that normative pressures prevail over coercive and mimetic pressures and are seen as the main drivers of sustainability in the manufacturing industry. In an incremental reductionist approach, project management knowledge areas are analysed, and the study posits that Stakeholder and Communications Management are two of the knowledge areas that need to integrate the above pressures to achieve cohesive sustainable industrial results. The principle contribution is to offer a new conceptual perspective on integrating project management knowledge areas with Institutional Theory pressures for more sustainable project management methodologies.
\end{abstract}

Keywords: sustainability constructs; sustainable project management; sustainability drivers; triple bottom line; institutional theory; organisational pressures; normative pressures

\section{Introduction}

The sustainable development concept gained recognition from the World Commission on Environment and Development (WCED) report in 1987 and introduced a formal definition of the concept as "development that meets the needs of the present without compromising the ability of future generations to meet their own needs" [1] (p. 16). The concept of sustainability addresses three main goals which are social (people), environmental (planet) and economic (profit) goals. Even though there is a plethora of sustainability definitions-around one hundred definitions are identified by [2] — most agree that sustainability addresses those three goals. Sometimes, these goals are referred to as pillars or objectives to sustainability [3-5], while other authors called it the Triple Bottom Line [6]. 
Sustainability in the manufacturing industry in terms of its environmental and social aspects is hardly novel [7]. This was supported by [8], where issues such as institutional pressures, global warming, and carbon footprint awareness can have a devastating impact if not properly addressed. Companies from different parts of the world have shown interest in sustainable and environmentally friendly manufacturing practices [9]. A holistic view on the manufacturing production processes and product design is needed in order to find sustainable solutions [10]. Life Cycle Assessment (LCA) is seen as key for most organisations pursuing sustainable development [11], while there is an emphasis on the need for stronger legislation and for education on sustainability [12]. The LCA core elements of the methodology have been presented in recent academic studies [11,12].

At the same time, project management has also seen a resurgence of academic and professional interest with a particular focus on sustainability influences. Project Management is defined as "the application of knowledge, skills, tools and techniques to project activities to meet project requirements" [13] and "projects do often have social, environmental and economic impacts that far outlast the projects themselves" [13]. This has led to the current thinking that project management can be viewed as the vehicle to successfully integrate projects with sustainability elements [14], and thus sparks mature discussions regarding sustainability in a project management context [15]. The environmental and social aspects of sustainability are not easily incorporated into programmes and projects [16], and scholars urge for further studies to understand the application of the Triple Bottom Line approach in project management [17]. The assumption that current project management standards are failing to comply with sustainability principles [15] reflects the current confusion in the field. Notwithstanding, previous studies have identified the following parameters where sustainability can be incorporated in project management: project lifecycle; regional, national, and international projects; ethicality in projects; clear policies and procedures for the projects; consideration for stakeholders' interest; managing uncertainty for sustainable projects; implementing JIT-KANBAN for waste elimination in projects; justified use of resources [18]. Incorporating sustainability principles into project management methodologies will transform the project management profession [15].

Project Management has become a salient approach adopted by businesses to survive, with the emergence of project management allies such as concurrent engineering, Total Quality Management (TQM), life cycle costing, and others [19]. All of these approaches are implemented mainly to provide clear view of project deliverables and traceability of project performance through Sustainable Project Life Cycle Management Framework [20]. Due to the project management framework's comprehensive approach and multi-industry universality and adaptability, the framework has been used as the basis for sustainable project management [13]. However, even though companies appreciate the value of implementing sustainability practices in project management, the implementation of these practices has been slow and challenging [21]. This is mainly due to the multi-dimensionality of sustainability and the functional-reductionist approach of project management constrained by the iron-triangle present a paradox with conflicting demands and foci.

The aim of this paper is to understand the implications of sustainability drivers towards manufacturing projects and specifically Project Management methodologies in the manufacturing industry. From the literature, it can be seen that these constructs are a form of pressure that companies are experiencing. Approaches already prevalent in the manufacturing industry are presented, such as Life Cycle Analysis, Lean Manufacturing, Environmental Management Systems and eco-design, and their appropriateness to be integrated with project management methodology is investigated. This study argues that dealing with manifesting stakeholder pressures is a key capability required by a project manager and the two knowledge areas from the Project Management Body of Knowledge (PMBOK) are used, namely Project Stakeholder and Project Communication management to respond to the sustainability imperative.

This study contributes to the body of knowledge on sustainability in project management by performing a systematic literature review of the drivers of sustainability in the manufacturing industry. 
This study marks an important contribution to our understanding of project management capabilities generally and practices for environmental and social benefit in projects in particular.

\section{Theoretical Background}

In recent decades, external influences on organisations have become exaggerated, demonstrated in the relentless pressures of accountability and assessment. As a response to these, organisational activities are expected to show a progressively wide range of features, particularly in areas such as the environment and social that may be far removed from production. Such regulatory challenges and pressures formed our research motivation in selecting the Triple Bottom Line (TBL) and Institutional Theory as the foundation for the literature review. The presence of waves of pressure explained by [22] depicts that the TBL and Institutional Theory are relatable. This is due to the fact that Institutional Theory deals with the pressures experienced by organisations to obtain legitimacy and be accepted by their society or environment. In other words, organisations around the globe aim to become sustainable according to the principles of the TBL. In this paper, the constructs of sustainability are reviewed in order to identify the most prominent one as the reason for organisations to be sustainable. Furthermore, Project Management methodologies are studies to identify the methods used by these organisations to address the constructs they experienced. The review of the two underlying theories is drawn from the wider existing literature, while the constructs and Project Management methodologies were specific to the manufacturing industry.

\subsection{Triple Bottom Line Framework}

Introduced in the year 1994 by Elkington (the founding father of TBL concept), the term Triple Bottom Line (TBL) is an accounting framework beyond the traditional measure of profits [23]. It promotes the assessment of business performance based on three important factors, which are economy, environment and social equity [22]. The following general definition for TBL was provided later [24] (p.12):

"[TBL] captures the essence of sustainability by measuring the impact of an organisation's activities on the world including both its profitability and shareholder values and its social, human and environmental capital".

Originally, Elkington was seeking an appropriate new definition expressing the inevitable growth of the environmental agenda by the environmental consultation company called "SustainAbility". At that time, the social and economic dimensions had already been flagged in the Brundtland Report [1], and those two dimensions could be addressed better if the actual progress on current environmental problems was addressed. In 1995, Elkington developed the 3P term, standing for people, planet and profit which correspond to the three elements of TBL [23].

\subsubsection{Measuring the Triple Bottom Line}

Environmental measurements are related to natural resources and their viability [23]. Examples of environmental variables include measuring sulphur dioxide concentration, concentration of nitrogen oxides, air and water quality, energy consumption, solid waste management and change in land use. Meanwhile, the social aspect encompasses the community or region of an area, where measurements can be made on education, health, well-being, life quality and social capital. Potential variables that can be assessed include rate of unemployment, average household income, and relative poverty [23].

With respect to all of the measurement variables above, an exact universal standard, unit or method in measuring the TBL is lacking. This is a benefit of the TBL framework as it enables users to apply the general framework depending on the needs and condition of the business [23], since different businesses have different processes, geographical boundaries and activities. An example is the Genuine Progress Indicator (GPI), which addresses the 3P factors, includes a total of twenty-five variables that are converted into financial units and cumulated onto a singular dollar-denominated unit of measurement [25]. In contrast, other organisations such as Cascade Engineering have used 
monetary units in measuring the amount of taxes pin (economic), unit of average hours of training per employee (social) and water consumption in litres for the environmental aspect of TBL [23]. Since the 1990s, there have been numerous efforts to formulate sustainable development indicators (SDIs), and many countries around the globe have developed their own regional sets of SCIs. However, no single SDI set has received universal acceptance.

\subsubsection{Waves of Pressures in Addressing Triple Bottom Line}

The first wave started in the early 1960s, where there was a need to limit demand of resources and be wary of environmental impacts. As a result, environmental legislation was addressed to the Organisation for Economic Co-operation and Development (OECD) and companies became compliant with the cause [22].

In 1988, the second pressure wave was triggered with the release of the report Our Common Future by the Brundtland Commission, where insights were provided regarding the requirement for development processes of new technologies to be sustainable, thus the term 'sustainable development'. In addition, issues such as rainforest destruction and depletion of ozone layer helped spark up the movement of green consumerism. In response, businesses became more competitive, and being sustainable is a competitive advantage [22].

The third pressure wave, which began in 1999 was due to the emergence of globalization, causing the necessity for the governance of a corporation to make changes to accommodate sustainable development in their business. This was addressed during the 2002 UN World Summit on Sustainable Development (WSSD). Due to globalization, the civil societies and governments were given a renewed focus and businesses are more market creation oriented [22].

In this study, it can be concluded that these waves of public pressures mainly focused on the environmental aspect of the TBL. In response to that, the roles and responsibilities of the public sector and governments changed with respect to each of these waves in order to reduce public concerns by instilling agendas of politics in businesses [22]. The challenge is to address the TBL in a more comprehensive approach, which would involve more stakeholders and addressing sustainability policies. As mentioned by Hall [23], measuring the sustainability categories is also a challenge, as relevant and sufficient data is required to get accurate results for a policy's contribution to sustainability. Nevertheless, the TBL framework is flexible and the measurements can be made suitable to the organisations' and industries' specific needs [23].

Below, Institutional Theory is introduced followed by a review of constructs of Sustainability in Manufacturing Industry. Then, a recapitulation is presented about how the specific pressures on sustainability practices impact on manufacturing practices.

\subsection{Institutional Theory}

Institutional Theory sets the foundation for analysing how pressures can influence an organisation [26]. The theory also provides a point of view where researchers can study the factors that drive survival and legitimacy of organisational practices. These include factors such as rules and regulations, culture, history and economic incentives [27-29]. 'Legitimacy' was explained as the practices of sustainability deemed appropriate and proper by the stakeholders involved [30]. In addition, Institutional Theory is traditionally fixated on how organisations are able to cope in securing their positions and legitimacy by adhering to the rules that exerted these conformance pressures within the institutional environment [30-33]. Therefore, organisations that achieve the desired goals will receive legitimacy and proved competent of resources by the society [34].

Different authors have had their own point of view regarding the benefits of Institutional Theory. Institutional theory can be used to portray changes in social values, advancement in technologies, regulations [35-37] and environmental management [38] in carrying out sustainable activities. Meanwhile, Ref. [39] used Institutional Theory to study the various organisational strategies in implementing environmental management practices. 
Nevertheless, there are several limitations of Institutional Theory, as it fails to fully describe the empirical findings in the literature presented by researchers who used Institutional Theory to describe variations in institutional diversity [40,41]. As an example, Ref. [40] mentioned that the theory assumed the one-way coercive effects of laws and regulations, which may inadvertently decrease or increase institutional diversity.

\section{Forms of Drivers for Institutional Theory}

Institutional Theory is distinguished between three forms of drivers, which are called coercive, normative and mimetic isomorphism, and which influence how organisations implement certain practices [26,30]. Decisions by organisations are not always determined by economic rationale [26] and this isomorphism is present in organisational structures, strategies and their processes [30].

Coercive isomorphism stems from influences of those in higher and powerful positions such as the government. Coercive pressures are important to ensure environmental management is fully functional in order to achieve sustainability [42]. Nevertheless, government regulation is not the only method of encouraging organisations to practice sustainable management. In fact, industrial or professional bodies commonly play an important role. Also known as normative pressure, it ensures organisational adherence in order to be viewed as participating in legitimate actions [43]. Members in an industry are expected to follow the rules and regulatory mechanisms created by the industrial associations. These rules include environmental standards to ensure environmentally responsible behaviour by companies. As Ball and Craig (2011) posit, normative isomorphism made organisations to be more environmentally conscious [35]. Institutional research is essential to comprehend the social rules and responses towards environmental problems faced by organisations. Some governments do encourage such self-regulation and complementally, industries felt they were better regulated by themselves through an association rather than coercive regulation by the government [44]. Therefore, normative drivers promote influence due to the social obligation to conform to what an organisation should be practicing [45].

Mimetic drivers are a form of imitation where companies copy the actions of prosperous competitors in their respective industry, hoping to replicate their success subsequently achieving legitimacy [43]. It is noted by Bansal (2005) that organisations imitating their top competitors are less frequently subjected to negative publicity, since legitimacy is often given when many organisations are doing the same, homogenous activities [46].

In short, institutions themselves have the ability to define that which is appropriate and legitimate, therefore rendering other actions as not acceptable or inconsiderable [31]. As a result, this will determine how organisations make decisions in their role to achieve conformity, regulatory and social pressures in their activities [47].

\subsection{Constructs of Sustainability in Manufacturing Industry}

Constructs of sustainability refer to drivers or triggering factors that lead a company to implement sustainable practices in their projects. The word "pressure" has been appearing extensively in the literature, and is identified as the general construct of sustainability. The pressure on companies to integrate values of sustainable development with their policies and activities is escalating [2]. Internal policies may vary among organisations and industries but they must ensure that the pursuit of economic growth is in line with environmental protection and provides benefits to the society. Examples may include collaboration with green suppliers, near sourcing, local recruitment, and so on. Companies have corporate responsibilities towards the society therefore pressure is ever present to align operational processes with the three pillars of sustainability [48]. This is not always easily accomplished though; for example, in the UK construction industry, the dominant sustainability dimension is the environmental one [49].

In addition, stakeholders are forcing companies to give more attention towards the social rather than the environmental part of sustainability, since the social part is generally seen as the weakest 
pillar of sustainable development. This was due to the lack of analytical and theoretical foundation of the subject [50]. Meanwhile, Ref. [8] also addressed that companies had been under pressure to include sustainable practices into their manufacturing operations. The researchers further elaborated that the pressures of promoting sustainable business practices came from three main dimensions: internal factors, external factors and management.

\subsubsection{Internal, External and Management Pressures}

Internal factors refers to the inside of an organisation, such as sustainability development strategies and organisational policies [7]. External factors are local laws, government regulations and market trends $[7,8]$. In relation to market trends, real business incentives also drive sustainable development [51]. As an example, in order to meet market needs, high-tech companies need to manufacture products that are sustainable to improve consumers' perception on the company's corporate social image [7]. Furthermore, the EU policies in Europe have promoted the financial, legal [52] and market pressures [53], on manufacturing industries to produce sustainable products.

Typically, the strategy of a company is based on and influenced by decisions from the management; therefore their attitude and mind-set towards sustainability is one of the key drivers in implementing sustainability development strategies [54]. Ref. [55] supported this claim, as in their study it was found that leaders who have a strong sense of guiding principles and shared values are more motivated to make better changes. Ref. [7] concluded that internal factors and management had higher value ( $\mu=4.87$ and 4.75 ) as motivating factors for sustainable development compared to external factors which is slightly lower $(\mu=4.56)$. The emergence of sustainability as a major global challenge has a significant impact on the decision-making processes of organisations and such decisions are considered strategic [56]. They also support the view that often, sustainability decisions can also be of an ad-hoc nature. Ad-hoc decisions in project management are investigated further in [57].

Meanwhile, the link between internal, external and managerial drivers with the three institutional pressures was explained in [58]. External drivers such as society, customers, suppliers, bank and insurance companies are normative pressures. A competitor is a mimetic pressure and anything related to government or legislations are coercive pressures. Top management and internal factors had no relation with any of the isomorphic pressures. A similar classification of drivers, although not examined under the umbrella of Institutional Theory, was provided by [56] in their conceptual work who classified the drivers of sustainability into exogenous and endogenous.

\subsubsection{Coercive Pressures}

Manufacturing companies have been operated within regulations related to production processes, specification of products and product performance [59,60]. The new regulations for having sustainable production processes place more emphasis on the environmental aspect of TBL. A number of environmental regulations that have impacted the manufacturing industry are Restriction of Hazardous Substances (RoHS), the EU Environmental Registration [61], Evaluation \& Authorization of Chemicals (REACH), the US EPA Toxic Release Inventory and the European Union's Waste Electrical and Electronic Equipment (WEEE) directive. This results in complexity for manufacturing operations to comply with these regulations due to different geographical locations or regions. Nevertheless, manufacturers respond to these regulatory pressures by introducing sustainable practices in their manufacturing operations [26]. On the other hand, companies keep themselves up to date with pre-legislative dialogues from the European Commission as a way to complement the needs of the legislation [62].

In another study [39], the authors pointed out that coercive pressures are strong, therefore any new government regulations are sufficient enough to stimulate organisations in adopting sustainable manufacturing practices. Their claim was based on the fact that organisations desire to improve their legitimacy and relationship with main institutional actors, thus adopting EMS. Likewise, a similar study was conducted by [63], verifying that there is a positive correlation between adoption of EMS 
and coercive isomorphic pressure. Similarly, the study of [64] also presented a similar result in India where institutional pressures are the strongest reason in adopting environmental strategies.

Studies conducted in China also came up with the same result. Coercive pressure from state regulations due to globalization is the primary driver in green supply chain manufacturing practices [65]. In addition, the research by [66] in Taiwan's apparel and textile industry revealed that the Taiwanese government's participation in pollution reduction and technology improvement initiatives has driven organisations to implement environmental practices.

\subsubsection{Normative Pressures}

Manufacturing companies operating in highly polluted industries such as petrochemicals, chemicals, metallurgy and nuclear energy are experiencing pressures from industry associations. These pressures are in the form of industry self-regulation and discredited rebellious organisations $[67,68]$. There have been situations where the credibility and legitimacy of the manufacturing industry was tarnished due to environmentally and socially irresponsible acts, but the number of incidents is few [69]. Therefore, industrial associations came up with their own environmental standards to shield the members of their organisations from the ever-increasing inspection of regulations to maintain legitimacy. As an example, the International Council of Chemical Associations introduced 'Responsible Care' to encourage organisations to practice environmentally sustainable behaviours. The initiative objectively wanted to improve the information about risks and management of chemicals in the supply chain. A total of 536 chemical manufacturing firms have shown their commitment in improving the social and environmental performance [70].

A similar example can be seen from Electronic Industry Alliance, which was established in 2008, where their role was to develop and implement process improvement with the goal to minimize the impact of e-waste on the environment. Top companies such as Hewlett Packard, Microsoft and Intel subscribed to this regulation thus showing normative isomorphism [69]. Likewise, the Green Electronic Council came up with Electronic Product Environmental Assessment Tool (EPEAT) that acts as a guidance in addressing environmental issues. The EPEAT managed to obtain regulative legitimacy in its operation when the United States administration recommended national agencies to acquire only products certified by EPEAT [26]. Nevertheless, self-regulatory laws are difficult to maintain without the presence of penalties and punishment [70].

Moreover, there is empirical evidence that companies faced pressure from trade associations and buyers in developed economies [71]. These companies, specifically in developed economies, may choose to commit to EMS as a sign of their commitment to environmental sustainability. As a result of that study, the researchers found that industrial clients prefer to conduct business with companies that are practicing sustainability in their processes. Thus, the normative pressure by the international trade association and buyers acted as the driver for companies to adopt sustainability practices in their manufacturing process. Meanwhile, it has been stated that corporate image is the primary driver for recycling wastes in a study among Japanese manufacturers compared to coercive pressure such as regulatory laws [72]. This is because the law has already been well established in Japan.

In addition, standards and norms related to a manufacturer's professional network within the same industry may influence another organisation. In other words, this will promote the host organisation to apply pressure on their partners of manufacturers and suppliers to adopt similar sustainable manufacturing practices [26]. On the other hand, self-regulation is becoming a clear source of pressure on manufacturing plants to adopt industrial pollution control standards in developing economies of South and Southeast Asia [73]. The authors additionally remarked that coercive pressures were weak in this region. Normative pressures also came from trade associations in export destinations, which played an important role in the implementation of sustainable manufacturing practices in key textile export countries such as Bangladesh, China, Cambodia and India [74]. The study in [61] also pointed out about self-regulation, where companies that obtained Environmental Management System 
certification (ISO 14001) release an environmental balance and policy report annually in order to view and display their investment performances in environmental strategies.

\subsubsection{Mimetic Pressures}

Organisations were feeling unsure of the benefits and effectiveness of sustainable management practices [46]. As a result of this uncertainty, this led organisations to imitate other organisations that had succeeded in their sustainability practices in order to obtain legitimacy. This supports the claim of [30], stating that companies desire to obtain positive coverage and public reputation and for that reason they imitate those they view as role-model leaders. As an example, manufacturing companies use benchmarking as a method of improving their production processes by mimicking their competitors [75]. Furthermore, similar behaviour can also be seen from Japanese manufacturers that adapted to mimetic isomorphism back in the 1990s [26].

In addition, feeling pressures from competition may result in organisations incorporating sustainable manufacturing practices in order not to risk the organisation being in an underprivileged position in relation to their competitors [26]. The study by [39] has shown that manufacturers adopt the ISO 14001 framework due to the presence of competitive pressure and losing competitive advantage. The researchers implied that "a high rate of sustainable manufacturing practice adoption by larger, successful firms will lead to competitive mimicry among other firms" [26] (p. 4).

\subsection{Project Management Methodologies in Manufacturing Industry}

The reaction by the majority of companies to sustainability came through the acquisition of Environmental Management Systems and developing annual sustainable reports of their operations. There was also an increased importance on Corporate Social Responsibility [2]. Research has shown that traditional business management systems were more financial-performance oriented, excluding social and environmental aspects of sustainability [2]. Therefore, practical tools that include sustainability elements within their evaluation processes are essential to align project management methodologies with the core principles of sustainable development [76]. It should be noted that organisations are accountable for the impact of projects to the triple bottom line even after the projects have finished [13]. The next section discusses some of the existing Project Management methodologies with sustainability elements in the manufacturing industry.

\subsubsection{Project Life Cycle Analysis}

A sustainability evaluation framework to assess projects during the early part of life cycle phases with respect to sustainability impacts of future implemented products and assets was developed by [77]. Initially, exact procedures to evaluate the environmental part of the operational activities were absent, but with proceeding research in 2005 the researchers introduced the environmental evaluation matrix (EEM) that takes environmental aspects into account as part of the project management practices in the manufacturing industry [78]. The EEM helped to improve the level to which sustainable development is evident in project management. The indicators of the environmental aspects of sustainability that have been proposed and used to develop the EEM were validated by [79]. The matrix was even tested on an actual case study in a South African process industry [77]. For its social aspects, the researchers highlighted that there is little consensus on which criteria should be taken into account for social performance evaluations. Overall, the Sustainability Evaluation Framework can be used for performance evaluations on business processes [19]. The crucial role of the environmental sustainability in obtaining sustainable manufacturing is described by [80]. The environmental LCA tool though fails to address the social impact of sustainability and that creates higher risks when decisions towards sustainability are based solely on environmental criteria [81]. This led to the need for an LCA methodology that would address the social and the economic dimensions of sustainability. Thus, the Social Life Cycle Assessment (SLCA), which enables the identification of the impact that the 
production, use, and disposal of products have on the society [82]. It is also true that the views and perceptions of the social impacts vary considerably among the SLCA approaches [83].

The quantitative social impact assessment method was inapplicable for project life cycle management due to the fact that the current available statistical data is incompetent of providing an integrated view of the various dimensions of sustainable development [84]. The researchers further noted that their conclusion arrived from a Process Life Cycle Assessment perspective, which is deemed more inclined to the industry sector. On the other hand, the research of [85] developed a two-dimensional managerial tool for sustainability management. The "sustainability progress" dimension of their tool increases with the effectiveness of the organisation to deal with social and environmental issues and the ability to content the needs of the stakeholders.

Meanwhile, using the Product Life Cycle methodology to integrate environmental information, such as product data and manufacturing data, which could benefit the product development and enhance relationship across the whole supply chain was proposed by [62]. On the contrary, a product life cycle assessment through an input-output analysis rather than using sustainability criteria indicators was performed by [9], and their analysis took into account various environmental issues. Their research noted that the use of multi-criteria has its own limitations; the fact that it was a subjective estimation meant that the results were difficult to replicate and be adapted to other scenarios [9]. The drawback of LCA, where there is absence of science-based methodology to define certain manufacturing processes to produce Life Cycle Inventory data, was pointed out in [86]. This is identified as a current technology limitation.

\subsubsection{Lean Manufacturing}

Lean Manufacturing is a Project Management Methodology based on the identification and reduction waste in various processes during production. A Lean Manufacturing framework by incorporating the environmental and social aspects of the TBL was proposed by [87]. The framework has Lean and Green performance indicators that can be used by organisations to benchmark their lean sustainable practices from other competitors.

There are many benefits of Lean Manufacturing. Eliminating waste can increase quality, improve customer response time, achieve better efficiency, increase profitability and reduce costs [88]. Furthermore, implementing Lean and Green practices simultaneously is much more effective and has a higher success rate of reducing waste, and it should be integrated with manufacturing systems [88]. This was supported by [87], as they claimed Lean and Green practices will increase profitability and competitive advantage of manufacturing companies, and Lean practices will result in competitive outcomes [89]. As an example, sustainable manufacturing practices, such as pollution prevention, are associated with better product quality and manufacturing costs. Findings by [90] suggested that practicing lean manufacturing is highly related to EMS practices. A study which investigated five types of Lean practices found out that four of them had a positive sustainable effect (Value Stream Mapping, Cellular Manufacturing, 5S and Total Productive Maintenance) [61]. This strengthens the arguments that in order to achieve credible environmental performance, lean practices play an important role as the mediator [53].

\section{Methodology}

The approach in identifying the constructs of sustainability and Project Management methodologies was through a qualitative analysis of a systematic literature review. In this research, no primary data was collected. There are two reasons as to the choice of qualitative approach for this research. Firstly, existing literature reviews on this subject are lacking. Existing reviews, although very helpful in identifying drivers and challenges in adopting sustainability, are fragmented and limited in identifying the main constructs of sustainability and Project Management methodologies simultaneously in the manufacturing industry. In response a new framing of sustainability is proposed here by examining specific project management methodologies in the manufacturing industry. 
Secondly, qualitative approaches are designed to unravel what actually happens in real life [38], thus, it allows researchers to learn people's opinion in the world they live in [91]. In other words, conducting a systematic literature review enables to unravel connections among different empirical findings [92], and it has the potential to provide the most important reasoning among different research papers [93].

This paper has an overarching intention for readers to obtain knowledge about sustainability practices in Project Management and to integrate project management knowledge areas with Institutional Theory pressures for more sustainable manufacturing project management methodologies.

To achieve that aim, two objectives were outlined: firstly, to identify the main constructs of sustainability in manufacturing projects and, how they integrate into a Project Management methodology; and secondly, to investigate the existing literature on the best practices Project Managers employ for sustainable Project Management. The research questions are:

1. What are the main constructs of sustainability in manufacturing projects?

2. Does the current literature regarding Project Management methodology contribute to sustainable manufacturing and if so, which method is the best practice in achieving sustainable Project Management?

3. From a project manager's point of view, how can these constructs be incorporated into the Project Management methodology?

\subsection{Research Sample}

The sampling strategy used is through filtration of keywords that are relevant for this research. Primarily, sustainability-, management-, production- and engineering-based articles related to the constructs were selected. Articles with primary focus on economic sustainability were rejected since the scope of the current research is on environmental and social aspects of the TBL.

Once the articles with related keywords were collected, those being published before the year 2001 were discarded from the systematic literature review process. The selected period, the years 2001 to 2017, was chosen as the authors were interested in the post-globalization period, which followed the third wave of pressure. It is noted that articles published before the year 2001 were used in the review of the literature but not for the constructs and Project Management methodologies in the systematic literature review.

\subsection{Overview of Information Needed}

To answer the first research question, the information needed were the constructs or drivers of sustainability. In particular, keywords such as "pressure", "external", "internal" and "managerial" were given attention. Meanwhile, the information needed for the second research question is to give attention to keywords such as "Sustainable practices", "Sustainable project management" and "methodology". For the third research question, the information is based on the results of the answers from the first two research questions.

For a qualitative study, there are four general areas of information that need to be satisfied [94]. Firstly, the information needs to be contextual. In other words, the context will be in the area of sustainability and project management. Next, the information needs to be perceptual, meaning that it must relate back to the research questions. Thirdly, the demographics of the information need to be set. There are no restrictions for the source of information in terms of geographical location, as long as it is in the scope of manufacturing industry. Lastly, the information needs to be based on theoretical information. For this paper, two theories were used, the Triple Bottom Line and Institutional Theory.

\subsection{Research Design Overview}

A systematic literature review addresses the problem from research questions by firstly identifying, critically evaluating and integrating the findings of those that are relevant and good quality research 
studies [93]. The literature review approach adopted in this study aligns with the systematic, explicit and reproducible method for management studies proposed by [95]. This type of literature review includes comprehensive searching, quality assessment and descriptive as well as narrative synthesis [96]. The eleven steps in the research design is presented in Figure 1.

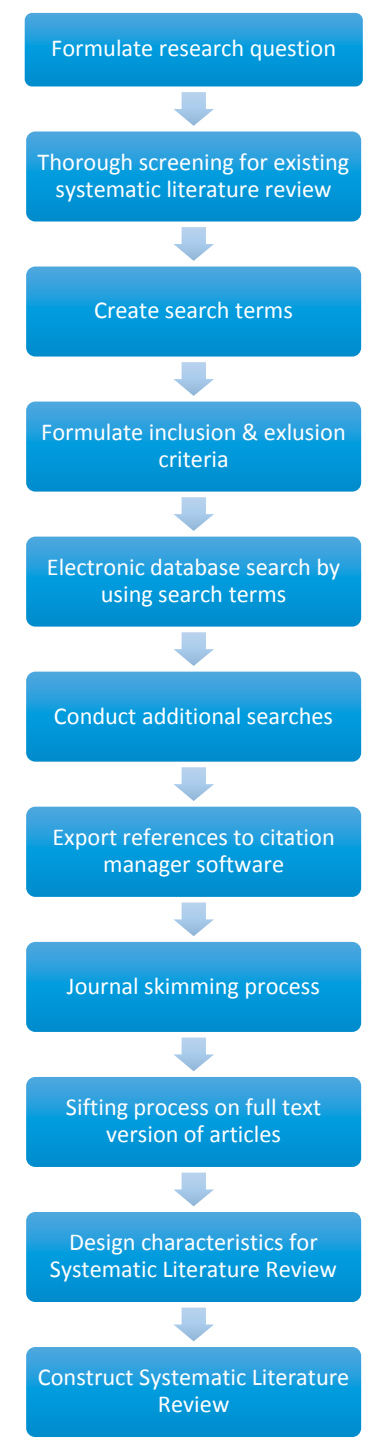

Figure 1. Research design flowchart.

The first step was to develop the research questions. They were designed to be relevant with the research findings which are the constructs and Project Management methodologies in the manufacturing industry. Step 2 was to make a thorough screening process for clarifying whether a similar systematic literature review has already been conducted in the past. To date, there are no known systematic literature reviews done specifically about the topic in the manufacturing sector.

The next step was to break the research questions into individual concepts to formulate search terms. Search terms are essential in finding relevant academic research. The search keywords operationalised here for each research question were:

- Research Question 1: "Constructs", "sustainability", "manufacturing", "projects"

- Research Question 2: "Project Management", "Methodology", "sustainable manufacturing", "best practices", "Lean Manufacturing", "Life Cycle" 
- Research Question 3: "Pressure", "Drivers", "Project Management Methodology", "Stakeholder", "Project Manager", "Project Management"

Alternative search terms which are synonyms were also used to broaden the search findings. As example, drivers and constructs were replaced by the word "causes" and the term "sustainability practices" was replaced by "green activities".

The inclusion criteria limited our search to academic peer reviewed journals from 2001-2017 that focussed on the manufacturing industry (Table 1). This is important to set the limitation and scope for information search. The articles that fulfilled all the inclusion criteria were saved for reading.

Table 1. Inclusion and exclusion criteria.

\begin{tabular}{ccc}
\hline Criteria & Included & Excluded \\
\hline TBL & Environmental and/or Social & Economic \\
Sector & Manufacturing & Healthcare, Oil \& gas, Supply Chain and others \\
Journal Timeframe & $2001-2017$ & Year 2000 and below \\
Source of Information & Academic Journals & Non-journals \\
\hline
\end{tabular}

Four bibliographic databases were utilised: ISI Web of Science; EBSCO; Scopus and Google Scholar. This literature review was further advanced by consolidating the academic journal's references using a citation manager software that enabled the researcher team to conduct the literature review independently and use the software to tag and gather references and communicate these through this scholarly database platform. The reference manager used is Elsevier Mendeley Desktop Version 1.17.9 (Elsevier, London, UK).

\subsection{Data-Collection Methods}

The skimming process of the selected articles was the eighth step in our research design. Initially, the title and abstract of each article were read. Where there was a presence of a construct, the article was downloaded and saved as potential information. Nevertheless, if the abstract did not refer to the drivers of sustainability but had the necessary information based on the inclusion criteria, the article was then saved and its main contents would be skimmed through for the constructs. Rejected articles, which were near the cut-off point, were documented in order to avoid repeated viewing.

Next step was the sifting process of the full text of the saved academic papers. Relevant information was extracted for the systematic literature review. At this stage, the focus shifted from sensitivity to specificity, where facts and critical points were searched and reviewed. In total, sixty-four academic articles were found related to the research question, but only twenty-eight of them were used for the systematic literature review. Some of the articles were discarded due to exclusion criteria and others because they were referring to previous research conducted by the same authors. The process is shown in Figure 2. The selection process demonstrated in Figure 2 resulted in the following list of journals where the articles were published (Table 2), forming the basis of the current research to answering the research questions. 


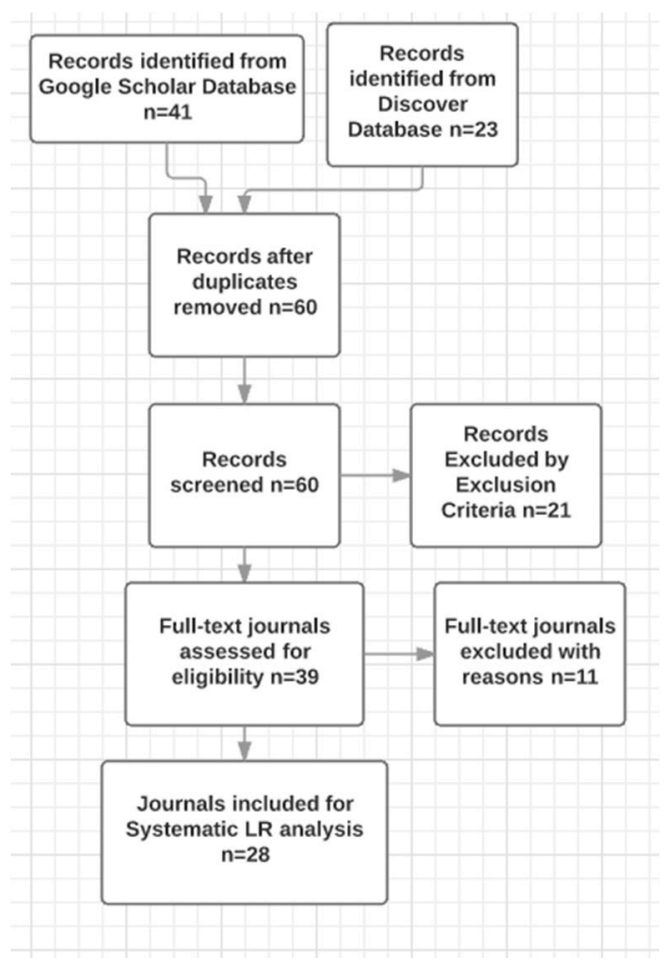

Figure 2. PRISMA flow diagram for article selection process.

Table 2. List of articles reviewed.

\begin{tabular}{cc}
\hline Journal Name & Articles \\
\hline Academy of Management Journal & 1 \\
American Journal of Political Science & 1 \\
Benchmarking: An International Journal & 1 \\
Business Strategy and the Environment & 2 \\
CIRP Annals-Manufacturing Technology & 1 \\
IEEE Transactions on Engineering Management & 1 \\
International Journal of Operations \& Production Management & 1 \\
International Journal of Production & 1 \\
International Journal of Production Economics & 1 \\
International Journal of Production Research & 2 \\
International Journal of Project Management & 1 \\
International Journal Production Economics & 1 \\
Journal of Business Logistics & 2 \\
Journal of Cleaner Production & 1 \\
Journal of Environmental Management & 5 \\
Journal of Operations Management & 1 \\
Management Research Review & 1 \\
Procedia CIRP & 1 \\
The International Journal of Life Cycle Assessment & 1 \\
The Policy Studies Journal & 1 \\
\hline
\end{tabular}

\subsection{Data Analysis and Synthesis}

The last step is the construction of the systematic literature review itself. The findings and information from academic articles were taxonomised into tables to allow for easy comparison between different studies. Table 3 is a synthesis of previous studies associated with sustainability practices within manufacturing and is organised according to the TBL scope and project management methodology. 
Table 3. Taxonomy of the Systematic Literature Review.

\begin{tabular}{|c|c|c|c|c|c|c|c|c|c|}
\hline No. & $\begin{array}{c}\text { Author(s) \& } \\
\text { Year }\end{array}$ & Title of Paper & Methodology & Main Findings/Outcome & $\begin{array}{l}\text { Constructs of } \\
\text { Sustainability }\end{array}$ & $\begin{array}{c}\text { PM } \\
\text { Methodology }\end{array}$ & $\begin{array}{l}\text { Limitation/Gaps in } \\
\text { Literature }\end{array}$ & TBL Scope & $\begin{array}{c}\text { Country of } \\
\text { Origin }\end{array}$ \\
\hline 1 & $\begin{array}{l}\text { Madu et al. } \\
\quad(2002)\end{array}$ & $\begin{array}{l}\text { A hierarchic metric } \\
\text { approach for integration } \\
\text { of green issues in } \\
\text { manufacturing: a paper } \\
\text { recycling application }\end{array}$ & $\begin{array}{c}\text { Quantitative analysis } \\
\text { by using analytic } \\
\text { hierarchy procedure } \\
\text { (AHP) }\end{array}$ & $\begin{array}{l}\text { Authors came up with a hierarchic } \\
\text { framework that integrates } \\
\text { stakeholders and product designers } \\
\text { to evaluate environmental burden. } \\
\text { The framework is usable to any } \\
\text { manufacturing projects }\end{array}$ & $\begin{array}{l}\text { External factor } \\
\text { (Stakeholder } \\
\text { pressure) }\end{array}$ & $\begin{array}{l}\text { LCA through } \\
\text { input-output } \\
\text { analysis }\end{array}$ & $\begin{array}{l}\text { Difficult to replicate the } \\
\text { same result as it is } \\
\text { based on human } \\
\text { decision and point of } \\
\text { views }\end{array}$ & Environment & U.S. \\
\hline 2 & $\begin{array}{l}\text { Maxwell \& van } \\
\text { der Vorst (2003) }\end{array}$ & $\begin{array}{l}\text { Developing sustainable } \\
\text { products and services }\end{array}$ & $\begin{array}{c}\text { Used Sustainable } \\
\text { Product \& Service } \\
\text { Development (SPSD) } \\
\text { approach by } \\
\text { incorporating into } \\
\text { Project Life Cycle } \\
\end{array}$ & $\begin{array}{l}\text { SPSD provided a practical approach } \\
\text { for companies in order to achieve } \\
\text { sustainable products and services. } \\
\text { This was supported based on } \\
\text { existing industry case studies. }\end{array}$ & $\begin{array}{c}\text { External factors } \\
\text { (Legal \& market } \\
\text { drivers) }\end{array}$ & LCA & N/A & $\begin{array}{l}\text { Environment } \\
\quad \& \text { Social }\end{array}$ & Ireland \\
\hline 3 & $\begin{array}{l}\text { Delmas \& Toffel } \\
\text { (2004) }\end{array}$ & $\begin{array}{l}\text { Stakeholders and } \\
\text { Environmental: } \\
\text { Management Practices: } \\
\text { An Institutional } \\
\text { Framework }\end{array}$ & $\begin{array}{l}\text { Empirical study by } \\
\text { using publicly } \\
\text { available databases \& } \\
\text { original data from } \\
\text { survey at plant }\end{array}$ & $\begin{array}{l}\text { The authors used institutional } \\
\text { theory at the theoretical framework } \\
\text { and proposed that stakeholders } \\
\text { imposed normative and coercive } \\
\text { pressures on companies }\end{array}$ & $\begin{array}{c}\text { Coercive greater } \\
\text { than Normative } \\
\text { Pressure }\end{array}$ & N/A & $\begin{array}{l}\text { No PM methodology } \\
\text { but discussed about } \\
\text { stakeholder } \\
\text { management which is } \\
\text { an area of knowledge } \\
\text { from PMBOK }\end{array}$ & $\begin{array}{l}\text { Environment } \\
\quad \& \text { Social }\end{array}$ & U.S. \\
\hline 4 & $\begin{array}{l}\text { Zhu \& Sarkis } \\
\quad(2004)\end{array}$ & $\begin{array}{l}\text { Relationships between } \\
\text { operational practices and } \\
\text { performance among early } \\
\text { adopters of green supply } \\
\text { chain management } \\
\text { practices in Chinese } \\
\text { manufacturing } \\
\text { enterprises }\end{array}$ & $\begin{array}{c}\text { Empirical analysis } \\
\text { from } 186 \text { respondents } \\
\text { on GCSM practice in } \\
\text { China manufacturing } \\
\text { industry }\end{array}$ & $\begin{array}{l}\text { Found multiple relationships among } \\
\text { GSCM practices and performance }\end{array}$ & $\begin{array}{l}\text { Coercive } \\
\text { pressure from } \\
\text { state regulation } \\
\text { due to } \\
\text { globalisation }\end{array}$ & N/A & $\begin{array}{l}\text { Does not specifically } \\
\text { mention what type of } \\
\text { GSCM \& no PM } \\
\text { methodology is } \\
\text { mentioned }\end{array}$ & Environment & China \\
\hline 5 & $\begin{array}{l}\text { King \& Lenox } \\
\quad(2004)\end{array}$ & $\begin{array}{c}\text { Industry Self-Regulation } \\
\text { Without Sanctions: The } \\
\text { Chemical Industry's } \\
\text { Responsible Care } \\
\text { Program }\end{array}$ & $\begin{array}{l}\text { Quantitative analysis } \\
\text { with empirical } \\
\text { methodology }\end{array}$ & $\begin{array}{l}\text { Findings shown that effective } \\
\text { industrial self-regulation is difficult } \\
\text { to maintain without the necessary } \\
\text { explicit sanctions }\end{array}$ & $\begin{array}{l}\text { Normative } \\
\text { pressure }\end{array}$ & $\mathrm{N} / \mathrm{A}$ & N/A & $\begin{array}{l}\text { Environment } \\
\quad \& \text { Social }\end{array}$ & U.S. \\
\hline 6 & $\begin{array}{l}\text { Labuschagne \& } \\
\text { Brent (2005) }\end{array}$ & $\begin{array}{l}\text { Sustainable Project Life } \\
\text { Cycle Management: the } \\
\text { need to integrate life } \\
\text { cycles in the } \\
\text { manufacturing sector }\end{array}$ & $\begin{array}{l}\text { Authors introduced a } \\
\text { Sustainable Project } \\
\text { LC management } \\
\text { framework }\end{array}$ & $\begin{array}{l}\text { Claimed that current Project } \\
\text { Management methodology does not } \\
\text { efficiently address the three } \\
\text { constraints of sustainable } \\
\text { development. }\end{array}$ & $\begin{array}{l}\text { Coercive } \\
\text { Pressure }\end{array}$ & LCA & $\begin{array}{l}\text { Does not specify } \\
\text { pressures were from } \\
\text { internal or external } \\
\text { pressure }\end{array}$ & $\begin{array}{l}\text { Environment } \\
\quad \& \text { Social }\end{array}$ & South Africa \\
\hline
\end{tabular}


Table 3. Cont.

\begin{tabular}{|c|c|c|c|c|c|c|c|c|c|}
\hline No. & $\begin{array}{c}\text { Author(s) \& } \\
\text { Year }\end{array}$ & Title of Paper & Methodology & Main Findings/Outcome & $\begin{array}{l}\text { Constructs of } \\
\text { Sustainability }\end{array}$ & $\begin{array}{c}\text { PM } \\
\text { Methodology }\end{array}$ & $\begin{array}{l}\text { Limitation/Gaps in } \\
\text { Literature }\end{array}$ & TBL Scope & $\begin{array}{c}\text { Country of } \\
\text { Origin }\end{array}$ \\
\hline 7 & $\begin{array}{l}\text { Labuschagne \& } \\
\text { Brent (2006) }\end{array}$ & $\begin{array}{l}\text { Social Indicators for } \\
\text { Sustainable Project and } \\
\text { Technology Life Cycle } \\
\text { Management in the } \\
\text { Process Industry }\end{array}$ & $\begin{array}{c}\text { Introduced } \\
\text { framework for social } \\
\text { sustainability criteria, } \\
\text { analysed using } \\
\text { Project Management } \\
\text { expertise }\end{array}$ & $\begin{array}{l}\text { Concluded that a quantitative social } \\
\text { impact assessment cannot be used to } \\
\text { the life cycle because data for social } \\
\text { footprint are not available at present }\end{array}$ & $\begin{array}{l}\text { Stakeholder } \\
\text { Pressures }\end{array}$ & LCA & $\begin{array}{l}\text { Environmental } \\
\text { calculation of } \\
\text { indicators is more } \\
\text { developed compared to } \\
\text { the social indicators, as } \\
\text { it is more measurable. }\end{array}$ & $\begin{array}{l}\text { Environment } \\
\quad \& \text { Social }\end{array}$ & South Africa \\
\hline 8 & $\begin{array}{c}\text { Prakash \& } \\
\text { Potoski (2006) }\end{array}$ & $\begin{array}{c}\text { Racing to the Bottom? } \\
\text { Trade, Environmental } \\
\text { Governance and ISO } \\
14001\end{array}$ & $\begin{array}{c}\text { Empirical analysis } \\
\text { based on panel study } \\
\text { of } 108 \text { countries in the } \\
\text { span of } 7 \text { years }\end{array}$ & $\begin{array}{l}\text { Studies shown that } \\
\text { non-governmental regimes such as } \\
\text { trade linkages encourage ISO } 14001 \\
\text { to be adopted if the countries major } \\
\text { export markets have used this as a } \\
\text { voluntary regulation. This } \\
\text { subsequently pressures home firms } \\
\text { to do the same and requires their } \\
\text { suppliers to adopt ISO } 14001 \text { as well }\end{array}$ & $\begin{array}{l}\text { Normative } \\
\text { Pressure }\end{array}$ & $\mathrm{N} / \mathrm{A}$ & $\begin{array}{c}\text { Talked about } \\
\text { management system } \\
\text { standards IS014001, no } \\
\text { PM methodology is } \\
\text { mentioned. }\end{array}$ & Environment & $\begin{array}{c}108 \\
\text { countries }\end{array}$ \\
\hline 9 & Jorgensen (2007) & $\begin{array}{c}\text { Towards more } \\
\text { sustainable management } \\
\text { systems: through life } \\
\text { cycle management and } \\
\text { integration }\end{array}$ & $\begin{array}{l}\text { Qualitative research } \\
\text { by introducing } \\
\text { different levels of } \\
\text { integration for } \\
\text { management systems }\end{array}$ & $\begin{array}{l}\text { Pointed out that firms should } \\
\text { further their attention to the entire } \\
\text { supply chain and strengthen } \\
\text { partnership with current } \\
\text { stakeholders in order to have more } \\
\text { sustainable management system }\end{array}$ & $\begin{array}{l}\text { Coercive } \\
\text { pressure } \\
\text { (regulation \& } \\
\text { market } \\
\text { pressure) }\end{array}$ & LCA & $\begin{array}{l}\text { Describes sustainability } \\
\text { management system, } \\
\text { and must be considered } \\
\text { in a life cycle } \\
\text { perspective. }\end{array}$ & $\begin{array}{l}\text { Environment } \\
\quad \& \text { Social }\end{array}$ & $\mathrm{N} / \mathrm{A}$ \\
\hline 10 & $\begin{array}{l}\text { Zhu \& Sarkis } \\
\text { (2007) }\end{array}$ & $\begin{array}{l}\text { The moderating effects of } \\
\text { institutional pressures on } \\
\text { emergent green supply } \\
\text { chain practices and } \\
\text { performance }\end{array}$ & $\begin{array}{l}\text { Used hierarchical } \\
\text { regression analysis } \\
\text { analysing data from } \\
341 \text { Chinese } \\
\text { manufacturer } \\
\text { respondents }\end{array}$ & $\begin{array}{l}\text { Results shown that manufacturers } \\
\text { that faced higher regulatory } \\
\text { pressures will implement } \\
\text { investment recovery initiatives and } \\
\text { green purchasing, while mimetic } \\
\text { pressures improve the economics of } \\
\text { GSCM practices with no negative } \\
\text { influences on environmental } \\
\text { performance. }\end{array}$ & $\begin{array}{l}\text { Coercive \& } \\
\text { Mimetic } \\
\text { Pressures }\end{array}$ & N/A & $\begin{array}{l}\text { No PM methodology, } \\
\text { but introduced } \\
\text { sustainability process } \\
\text { such as eco-design and } \\
\text { green purchasing. The } \\
\text { study does not fully } \\
\text { elaborate on how and } \\
\text { why these isomorphic } \\
\text { pressures exist }\end{array}$ & Environment & China \\
\hline 11 & Rusinko (2007) & $\begin{array}{l}\text { Green Manufacturing: } \\
\text { An Evaluation of } \\
\text { Environmentally } \\
\text { Sustainable } \\
\text { Manufacturing Practices } \\
\text { and their impact on } \\
\text { competitive outcomes }\end{array}$ & $\begin{array}{l}\text { Exploratory study of } \\
\text { previous studies }\end{array}$ & $\begin{array}{l}\text { Implied that environmentally } \\
\text { sustainable practices may be } \\
\text { positively related with competitive } \\
\text { outcomes }\end{array}$ & $\begin{array}{l}\text { External factors } \\
\text { (Stakeholder } \\
\text { Pressures) }\end{array}$ & $\begin{array}{c}\text { Lean } \\
\text { Manufacturing }\end{array}$ & $\begin{array}{l}\text { The study is limited to } \\
\text { only one industry } \\
\text { which is the U.S. } \\
\text { commercial carpet } \\
\text { industry and shortage } \\
\text { sources of legit } \\
\text { secondary data }\end{array}$ & Environment & U.S. \\
\hline
\end{tabular}


Table 3. Cont.

\begin{tabular}{|c|c|c|c|c|c|c|c|c|c|}
\hline No. & $\begin{array}{c}\text { Author(s) \& } \\
\text { Year }\end{array}$ & Title of Paper & Methodology & Main Findings/Outcome & $\begin{array}{l}\text { Constructs of } \\
\text { Sustainability }\end{array}$ & $\begin{array}{c}\text { PM } \\
\text { Methodology }\end{array}$ & $\begin{array}{c}\text { Limitation/Gaps in } \\
\text { Literature }\end{array}$ & TBL Scope & $\begin{array}{c}\text { Country of } \\
\text { Origin }\end{array}$ \\
\hline 12 & $\begin{array}{l}\text { Darnall \& Sides } \\
\quad(2008)\end{array}$ & $\begin{array}{c}\text { Assessing the } \\
\text { Performance of Voluntary } \\
\text { Environmental Programs: } \\
\text { Does Certification } \\
\text { Matter? }\end{array}$ & $\begin{array}{l}\text { Used meta-analysis } \\
\text { by evaluating } \\
\text { aggregated } \\
\text { environmental } \\
\text { outcomes of VEP } \\
\text { from } 9 \text { studies and } \\
\text { over } 30,000 \text { firms in } \\
\text { the U.S. }\end{array}$ & $\begin{array}{l}\text { VEP does not improve } \\
\text { environmental performance of the } \\
\text { participators, but in fact } \\
\text { non-participants had } 7.7 \% \\
\text { improvement more on their } \\
\text { environmental performance }\end{array}$ & $\begin{array}{l}\text { Coercive } \\
\text { pressure }\end{array}$ & N/A & $\begin{array}{l}\text { VEP is more of a } \\
\text { programme } \\
\text { incorporated as a } \\
\text { sustainable practice, } \\
\text { not a PM methodology }\end{array}$ & Environment & U.S. \\
\hline 13 & Sangle (2010) & $\begin{array}{c}\text { Empirical Analysis of } \\
\text { Determinants of } \\
\text { Adoption of Proactive } \\
\text { Environmental Strategies } \\
\text { in India }\end{array}$ & $\begin{array}{l}\text { Used primary and } \\
\text { secondary sources of } \\
\text { information. SSPS } \\
\text { version } 14.0 \text { was used } \\
\text { for data analysis and } \\
\text { statistics tool. } \\
\end{array}$ & $\begin{array}{l}\text { Institutional pressure is the most } \\
\text { prominent reason for adaptation of } \\
\text { proactive environmental strategies }\end{array}$ & $\begin{array}{l}\text { General } \\
\text { institutional } \\
\text { pressure }\end{array}$ & $\mathrm{N} / \mathrm{A}$ & $\begin{array}{l}\text { Relatively small } \\
\text { cross-sectional sample } \\
\text { which only could } \\
\text { support correlation } \\
\text { rather than a full } \\
\text { analysis } \\
\end{array}$ & Environment & India \\
\hline 14 & Zhu et al. (2010) & $\begin{array}{l}\text { Green supply chain } \\
\text { management in leading } \\
\text { manufacturers: Case } \\
\text { studies in Japanese large } \\
\text { companies }\end{array}$ & $\begin{array}{c}\text { Comparative analysis } \\
\text { of nine large Japanese } \\
\text { manufacturers with } \\
\text { Chinese } \\
\text { manufacturers }\end{array}$ & $\begin{array}{l}\text { Japanese manufacturers did more } \\
\text { effectively in implementing one key } \\
\text { of GSCM practice, internal } \\
\text { environmental management } \\
\text { compared to Chinese manufacturers. } \\
\text { Remaining GSCM practices which } \\
\text { were customer cooperating with } \\
\text { environment, eco-design, } \\
\text { investment recovery and green } \\
\text { purchasing, were on the same level }\end{array}$ & $\begin{array}{l}\text { Normative } \\
\text { pressure } \\
\text { (corporate } \\
\text { image) }\end{array}$ & N/A & $\begin{array}{l}\text { A larger survey would } \\
\text { be needed with more } \\
\text { responses compared to } \\
\text { only } 9 \text { which is a very } \\
\text { small sample size }\end{array}$ & Environment & Japan \\
\hline 15 & $\begin{array}{l}\text { Yang et al. } \\
\text { (2011) }\end{array}$ & $\begin{array}{c}\text { Impact of lean } \\
\text { manufacturing and } \\
\text { environmental } \\
\text { management on business } \\
\text { performance: An } \\
\text { empirical study of } \\
\text { manufacturing firms } \\
\end{array}$ & $\begin{array}{l}\text { Empirical study with } \\
\text { data from } 309 \\
\text { international } \\
\text { manufacturers } \\
\text { (IMSSS IV) by using } \\
\text { AMOS }\end{array}$ & $\begin{array}{c}\text { Lean manufacturing experiences are } \\
\text { positively associated to } \\
\text { environmental management } \\
\text { activities }\end{array}$ & $\begin{array}{l}\text { Coercive } \\
\text { pressure }\end{array}$ & $\begin{array}{c}\text { Lean } \\
\text { Manufacturing }\end{array}$ & $\begin{array}{l}\text { Single item of measure } \\
\text { was used for this } \\
\text { research }\end{array}$ & Environment & U.S. \\
\hline 16 & Tate et.al. (2011) & $\begin{array}{l}\text { Transaction Cost and } \\
\text { Institutional Drivers of } \\
\text { Supplier Adoption of } \\
\text { Environmental Practices }\end{array}$ & $\begin{array}{l}\text { Used institutional } \\
\text { theory as theoretical } \\
\text { framework and } \\
\text { transaction cost } \\
\text { analysis for analysing } \\
\text { supplier adoption to } \\
\text { sustainable practice }\end{array}$ & $\begin{array}{l}\text { Analysis shown that if coercive, } \\
\text { normative and mimetic pressures } \\
\text { are present, therefore supplier } \\
\text { adoption to environmental practices } \\
\text { is more likely }\end{array}$ & $\begin{array}{l}\text { Coercive, } \\
\text { Normative \& } \\
\text { Mimetic } \\
\text { pressures }\end{array}$ & N/A & $\begin{array}{l}\text { Does not mention } \\
\text { which one is the } \\
\text { strongest amongst } 3\end{array}$ & Environment & $\begin{array}{c}\text { Not } \\
\text { Specified }\end{array}$ \\
\hline
\end{tabular}


Table 3. Cont.

\begin{tabular}{|c|c|c|c|c|c|c|c|c|c|}
\hline No. & $\begin{array}{c}\text { Author(s) \& } \\
\text { Year }\end{array}$ & Title of Paper & Methodology & Main Findings/Outcome & $\begin{array}{l}\text { Constructs of } \\
\text { Sustainability }\end{array}$ & $\begin{array}{c}\text { PM } \\
\text { Methodology }\end{array}$ & $\begin{array}{l}\text { Limitation/Gaps in } \\
\text { Literature }\end{array}$ & TBL Scope & $\begin{array}{c}\text { Country of } \\
\text { Origin }\end{array}$ \\
\hline 17 & Qi et al. (2011) & $\begin{array}{l}\text { Diffusion of ISO } 14001 \\
\text { environmental } \\
\text { management systems in } \\
\text { China: rethinking on } \\
\text { stakeholder's roles }\end{array}$ & $\begin{array}{l}\text { Empirical analysis of } \\
\text { using panel data of } \\
\text { ISO } 14001 \\
\text { certification from } \\
\text { period 2004-2008 }\end{array}$ & $\begin{array}{l}\text { Community stakeholders \& foreign } \\
\text { customers plays significant role in } \\
\text { promoting usage of ISO } 14001 \\
\text { certification }\end{array}$ & $\begin{array}{l}\text { Normative } \\
\text { Pressure }\end{array}$ & N/A & $\begin{array}{c}\text { Talked about } \\
\text { environmental } \\
\text { management system as } \\
\text { a tool but not a PM } \\
\text { methodology }\end{array}$ & Environment & China \\
\hline 18 & Wu et al. (2012) & $\begin{array}{c}\text { The effects of GSCM } \\
\text { drivers and institutional } \\
\text { pressures on GSCM } \\
\text { practices in Taiwan's } \\
\text { textile and apparel } \\
\text { industry }\end{array}$ & $\begin{array}{c}\text { Empirical study } \\
\text { using hierarchical } \\
\text { moderated regression } \\
\text { analysis }\end{array}$ & $\begin{array}{l}\text { Regulatory pressure has positive } \\
\text { relation to most relationships } \\
\text { between GSCM drivers and } \\
\text { practices compared to market } \\
\text { pressure which had no moderating } \\
\text { effect }\end{array}$ & $\begin{array}{l}\text { Coercive } \\
\text { Pressures }\end{array}$ & N/A & $\begin{array}{l}\text { Does not take social } \\
\text { factor into account }\end{array}$ & Environment & Taiwan \\
\hline 19 & $\begin{array}{l}\text { Law \& } \\
\text { Gunasekaran } \\
\quad(2012)\end{array}$ & $\begin{array}{l}\text { Sustainability } \\
\text { development in high-tech } \\
\text { manufacturing firms in } \\
\text { Hong Kong: Motivators } \\
\text { and readiness }\end{array}$ & $\begin{array}{l}\text { Used quantitative } \\
\text { data from } \\
\text { questionnaires } \\
\text { answered by } \\
\text { managers and } \\
\text { professionals of } \\
\text { high-tech } \\
\text { manufacturing } \\
\text { companies }\end{array}$ & $\begin{array}{l}\text { Internal factors were the significant } \\
\text { motivating factor to adopt } \\
\text { sustainability practices }\end{array}$ & Internal factors & $\mathrm{N} / \mathrm{A}$ & $\begin{array}{l}\text { Scope \& sample size is } \\
\text { too small, but the } \\
\text { methodology is } \\
\text { credible enough and } \\
\text { promising }\end{array}$ & Environment & $\begin{array}{l}\text { Hong Kong } \\
\text { China }\end{array}$ \\
\hline 20 & $\begin{array}{l}\text { Hong et al. } \\
\text { (2012) }\end{array}$ & $\begin{array}{l}\text { Benchmarking } \\
\text { sustainability practices: } \\
\text { evidence from } \\
\text { manufacturing firms }\end{array}$ & $\begin{array}{l}\text { Quantitative based } \\
\text { research from } 379 \\
\text { companies by using } \\
\text { structural equation } \\
\text { modelling }\end{array}$ & $\begin{array}{l}\text { Companies that practices Lean } \\
\text { Manufacturing have positive effect } \\
\text { on environmental performance and } \\
\text { their suppliers acts as supporting } \\
\text { party in upholding that performance }\end{array}$ & External factors & $\begin{array}{c}\text { Lean } \\
\text { Manufacturing }\end{array}$ & $\begin{array}{l}\text { Limitation of } \\
\text { information obtained } \\
\text { were from personnel at } \\
\text { the plant level }\end{array}$ & Environment & U.S. \\
\hline 21 & $\begin{array}{l}\text { Gunasekaran } \\
\text { and Spalanzani } \\
\text { (2012) }\end{array}$ & $\begin{array}{l}\text { Sustainability of } \\
\text { manufacturing and } \\
\text { services: Investigations } \\
\text { for research and } \\
\text { applications }\end{array}$ & $\begin{array}{l}\text { Qualitative } \\
\text { methodology that } \\
\text { reviews the literature } \\
\text { in sustainable } \\
\text { business } \\
\text { development from } \\
\text { year } 2000 \text { to } 2010\end{array}$ & $\begin{array}{l}\text { Authors developed a sustainable } \\
\text { development framework with } \\
\text { techniques, tools and strategies }\end{array}$ & $\begin{array}{l}\text { External and } \\
\text { Internal factors }\end{array}$ & $\mathrm{N} / \mathrm{A}$ & $\begin{array}{l}\text { There are gaps in } \\
\text { framework for scholars } \\
\text { and practitioners to } \\
\text { develop ideas into } \\
\text { sustainable } \\
\text { development }\end{array}$ & $\begin{array}{l}\text { Environment } \\
\text { \& Social }\end{array}$ & $\begin{array}{c}\text { Not } \\
\text { Specified }\end{array}$ \\
\hline 22 & Bey et al. (2013) & $\begin{array}{c}\text { Drivers and barriers for } \\
\text { implementation of } \\
\text { environmental strategies } \\
\text { in manufacturing } \\
\text { companies }\end{array}$ & International survey & $\begin{array}{l}\text { There is lack of information on } \\
\text { impacts to the environment, } \\
\text { shortage of resources and expertise } \\
\text { in the field }\end{array}$ & $\begin{array}{l}\text { Coercive } \\
\text { Pressure }\end{array}$ & LCA & $\mathrm{N} / \mathrm{A}$ & Environment & $\begin{array}{c}\text { Denmark \& } \\
\text { U.S. }\end{array}$ \\
\hline
\end{tabular}


Table 3. Cont

\begin{tabular}{|c|c|c|c|c|c|c|c|c|c|}
\hline No. & $\begin{array}{c}\text { Author(s) \& } \\
\text { Year }\end{array}$ & Title of Paper & Methodology & Main Findings/Outcome & $\begin{array}{l}\text { Constructs of } \\
\text { Sustainability }\end{array}$ & $\begin{array}{c}\text { PM } \\
\text { Methodology }\end{array}$ & $\begin{array}{l}\text { Limitation/Gaps in } \\
\text { Literature }\end{array}$ & TBL Scope & $\begin{array}{c}\text { Country of } \\
\text { Origin }\end{array}$ \\
\hline 23 & Chiarini (2014) & $\begin{array}{c}\text { Sustainable } \\
\text { manufacturing-greening } \\
\text { processes using specific } \\
\text { Lean Production tools: an } \\
\text { empirical observation } \\
\text { from European } \\
\text { motorcycle component } \\
\text { manufacturers }\end{array}$ & $\begin{array}{l}\text { Empirical study } \\
\text { based on } 5 \text { case } \\
\text { studies }\end{array}$ & $\begin{array}{l}\text { Lean Production tools brings } \\
\text { positive outcome to environmental } \\
\text { management }\end{array}$ & $\begin{array}{c}\text { Coercive \& } \\
\text { Normative } \\
\text { Pressure }\end{array}$ & $\begin{array}{c}\text { Lean } \\
\text { Manufacturing }\end{array}$ & $\begin{array}{c}\text { There is no specific } \\
\text { theoretical framework } \\
\text { about Lean Production } \\
\text { tools from the } \\
\text { Literature Review }\end{array}$ & Environment & Europe \\
\hline 24 & $\begin{array}{l}\text { Verrier et al. } \\
\quad(2014)\end{array}$ & $\begin{array}{c}\text { Combining } \\
\text { organizational } \\
\text { performance with } \\
\text { sustainable development } \\
\text { issues: The Lean and } \\
\text { Green project } \\
\text { benchmarking repository }\end{array}$ & $\begin{array}{l}\text { Case study research } \\
\text { methodology on the } \\
\text { practices of } 21 \\
\text { Alsatian industrial } \\
\text { companies }\end{array}$ & $\begin{array}{l}\text { Proposed a framework for Lean \& } \\
\text { Green Management that } \\
\text { encompasses Lean Indicators, Green } \\
\text { intention and performance } \\
\text { indicators }\end{array}$ & $\begin{array}{l}\text { Mimetic } \\
\text { Pressure } \\
\text { (competition \& } \\
\text { competitive } \\
\text { advantage) }\end{array}$ & $\begin{array}{c}\text { Lean } \\
\text { Manufacturing }\end{array}$ & N/A & $\begin{array}{l}\text { Environment } \\
\quad \& \text { Social }\end{array}$ & France \\
\hline 25 & $\begin{array}{l}\text { Mani et al. } \\
\text { (2014) }\end{array}$ & $\begin{array}{c}\text { Sustainability } \\
\text { characterisation for } \\
\text { manufacturing processes }\end{array}$ & $\begin{array}{l}\text { Qualitative analysis } \\
\text { through a literature } \\
\text { study }\end{array}$ & $\begin{array}{l}\text { Did an energy \& materials based } \\
\text { metrics to evaluate environmental } \\
\text { performance sustainability }\end{array}$ & N/A & LCA & $\mathrm{N} / \mathrm{A}$ & Environment & U.S. \\
\hline 26 & $\begin{array}{c}\text { Tachizawa et al. } \\
\text { (2015) }\end{array}$ & $\begin{array}{l}\text { Green supply chain } \\
\text { management approaches: } \\
\text { drivers and performance } \\
\text { implications }\end{array}$ & $\begin{array}{l}\text { From the results of a } \\
\text { survey, data were } \\
\text { processed to test a } \\
\text { model that relates to } \\
3 \text { different variables } \\
\text { surrounding GSCM }\end{array}$ & $\begin{array}{l}\text { Findings shown that coercive } \\
\text { pressures have negative impact } \\
\text { compared to non-coercive drivers } \\
\text { when practicing GSCM. }\end{array}$ & $\begin{array}{l}\text { Coercive, } \\
\text { Normative \& } \\
\text { Mimetic } \\
\text { Pressures }\end{array}$ & N/A & $\begin{array}{l}\text { Sample size is small, } \\
\text { data is limited to only } 1 \\
\text { country }\end{array}$ & Environment & Spain \\
\hline 27 & Nappi (2015) & $\begin{array}{l}\text { The Incorporation of } \\
\text { Sustainability Indicators } \\
\text { into a Performance } \\
\text { Measurement System }\end{array}$ & $\begin{array}{l}\text { Empirical study by } \\
\text { using semi-structured } \\
\text { interviews and data } \\
\text { collection from } \\
\text { company's internal } \\
\text { documents, } \\
\text { information system \& } \\
\text { technical reports }\end{array}$ & $\begin{array}{l}\text { Findings shown that if stakeholders } \\
\text { are interested in sustainable } \\
\text { development, therefore it is possible } \\
\text { to integrate sustainable performance } \\
\text { indicators into the PMS }\end{array}$ & $\begin{array}{l}\text { Normative } \\
\text { pressure } \\
\text { (Customer } \\
\text { Demands) }\end{array}$ & N/A & $\begin{array}{c}\text { Outcomes are limited } \\
\text { to particular context } \\
\text { since the results were } \\
\text { from action research }\end{array}$ & Environment & Brazil \\
\hline 28 & $\begin{array}{c}\text { Shubham et al. } \\
\text { (2016) }\end{array}$ & $\begin{array}{l}\text { Organizational adoption } \\
\text { of sustainable } \\
\text { manufacturing practices } \\
\text { in India: integrating } \\
\text { institutional theory and } \\
\text { corporate environmental } \\
\text { responsibility }\end{array}$ & $\begin{array}{l}\text { Empirical study } \\
\text { using institutional } \\
\text { theory as theoretical } \\
\text { framework and } \\
\text { sample from primary } \\
\text { database }\end{array}$ & $\begin{array}{l}\text { Concluded that sustainable } \\
\text { manufacturing practices were } \\
\text { influenced from normative pressure } \\
\text { compared to coercive and mimetic }\end{array}$ & $\begin{array}{l}\text { Normative } \\
\text { Pressure }\end{array}$ & N/A & $\begin{array}{l}\text { Adopted towards } \\
\text { sustainable practise \& } \\
\text { tools such as } \\
\text { eco-design, source } \\
\text { reduction \& EMS, not } \\
\text { Project Management } \\
\text { methodology in } \\
\text { particular. }\end{array}$ & $\begin{array}{l}\text { Environment } \\
\quad \& \text { Social }\end{array}$ & India \\
\hline
\end{tabular}




\section{Analysis and Discussion}

In this section, the discussion unfolds in terms of identifying the theoretical constructs of sustainability with respect to the manufacturing industry and identifying the project management methodological approaches capable of addressing these sustainability drivers. To this end, the authors posit that generative mechanisms in the Communication and Stakeholder Management areas of knowledge of the PMI PMBOK would be able to resolve some of the dichotomies between sustainability and productivity.

\subsection{The Main Constructs of Sustainability in Manufacturing Projects (Research Question 1)}

It is noted from the literature that there is a plethora of drivers for manufacturing companies to implement sustainable practices, mainly due to internal and external factors. There were other factors not clearly stated if they were internal or external pressures such as stakeholder and managerial pressures. Meanwhile, specific type of pressures were the three institutional pressures: mimetic, normative and coercive pressures, where the latter was a branch originating from external pressure. Since the theoretical framework of this work is TBL and Institutional Theory, it is an apparent assumption that the constructs were to address the environmental and social aspects of sustainability and the term "pressure" was seen as its triggering factor. Examining the Organisational and Operations Management literature, Internal and External Factors (addressed as Other Pressures) are suggested as the least important constructs of sustainability. Some studies suggest that sustainability pressures stemmed from external stakeholders [9,52], while others do not clearly state if their constructs are derived from external and/or internal pressures $[8,84]$. These diverse findings suggest that most papers have not been framed clearly or rigorously to identify sustainability constructs, as it concerns the Institutional Theory. While Law and Gunakesaran (2012) did mention internal factors as a significant motivating factor to be sustainable, their scope and research sample size is too small [7] (only in Hong Kong). Meanwhile, other research was limited in terms of its information were only collected at the plant level [53].

The literature also suggests that mimetic pressure was not the main sustainability construct $[64,69]$. Lean and Green Manufacturing approaches have been identified as promoting competitive advantage in terms of manufacturers learning from each other's lean practices to become better than their competitors [87]. As only five authors mentioned Mimetic pressure as a construct of sustainability, it is easy to presume that mimetic pressure is the less prominent sustainability construct (Figure 3).

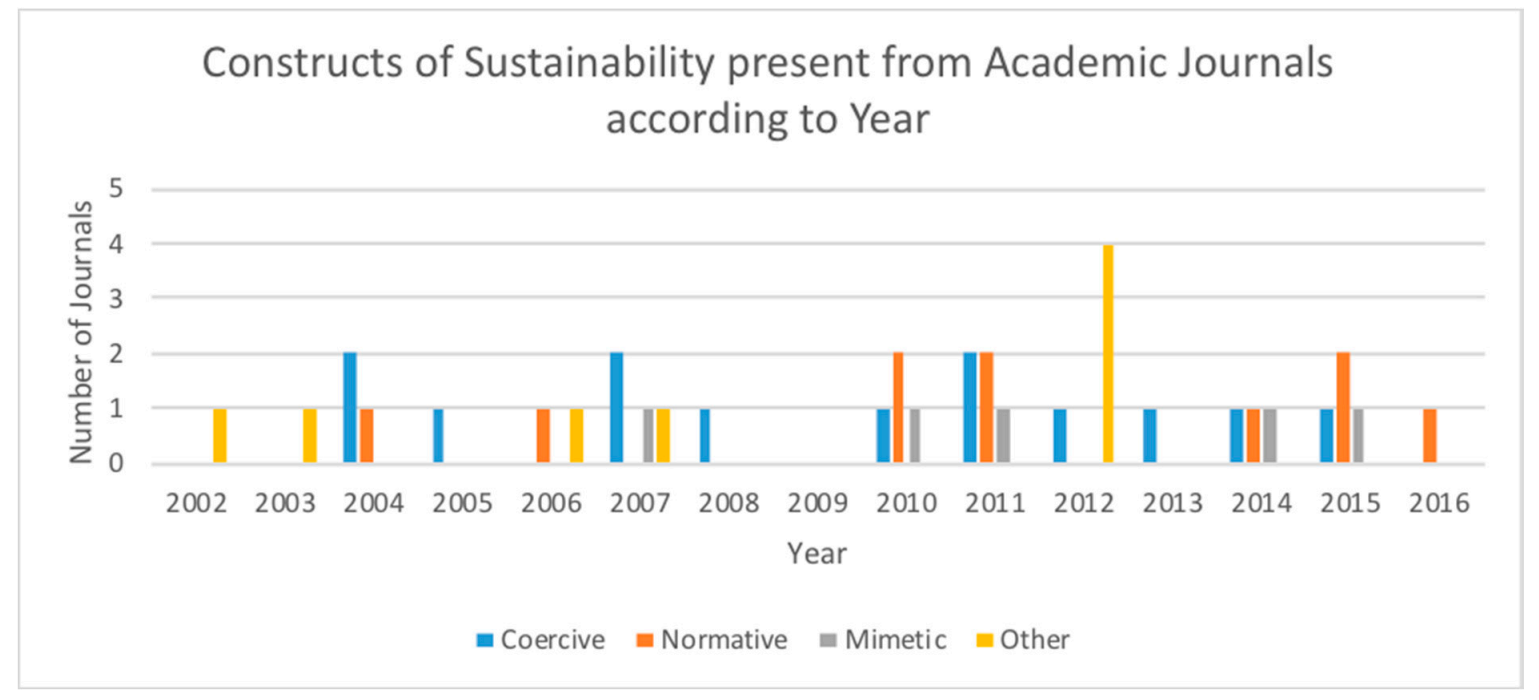

Figure 3. Constructs of sustainability. 
In contrast, it was noted from the literature review that the most cited construct (13 occurrences since 2001) was that of Coercive Pressure [2,10,63-65,69,90,97]. Interestingly, Ref. [58] concluded that coercive pressure brought negative impact to GSCM practices; also imposed coercive pressure to be greater than normative pressure [39]. In reporting their findings, [62,66] conducted a hierarchical regression analysis and both indicated that regulatory pressure was vital in achieving sustainability among companies.

Meanwhile, normative pressure also featured as a prominent cause for companies to become sustainable in the literature review [64,69]. More specifically, several authors invoke that normative isomorphism is evident in the form of quality management standards [71,74] to meet customer demands [98], and to maintain a good corporate image [72]. The dominance of normative isomorphism in organisational sustainability adoption has continuously grown since 2010 suggests the emergence of normative isomorphism (Figure 3). Research by [61] reiterated this trend by tracing change from maintaining EU regulation to self-regulation within the industry. In reporting their findings, Ref. [26] claimed that self-regulatory bodies such as industrial associations and Non-Governmental Organizations (NGOs) "monitor firms' environmental performance, and help in building a normative institution environment to encourage firms to adopt sustainable management practices" [26] (p. 10). In addition, non-coercive pressure was seen to bring positive environmental impact compared to coercive pressures [58].

Thus, from recent literature this study posits that sustainability drivers in the manufacturing industry would be dominated by normative pressure. Nevertheless, coercive pressure will continue to be evident in the next step in achieving sustainability is through the self-regulation of professional bodies within the industry.

\subsection{Project Management Methodological Approaches Capable of Addressing Sustainability Drivers in Manufacturing (Research Question 2)}

In this discussion section, a review of whether the current Project Management Methodologies contribute to sustainable manufacturing is undertaken and the method is identified as the best practice in achieving sustainable Project Management in projects (Figure 4).

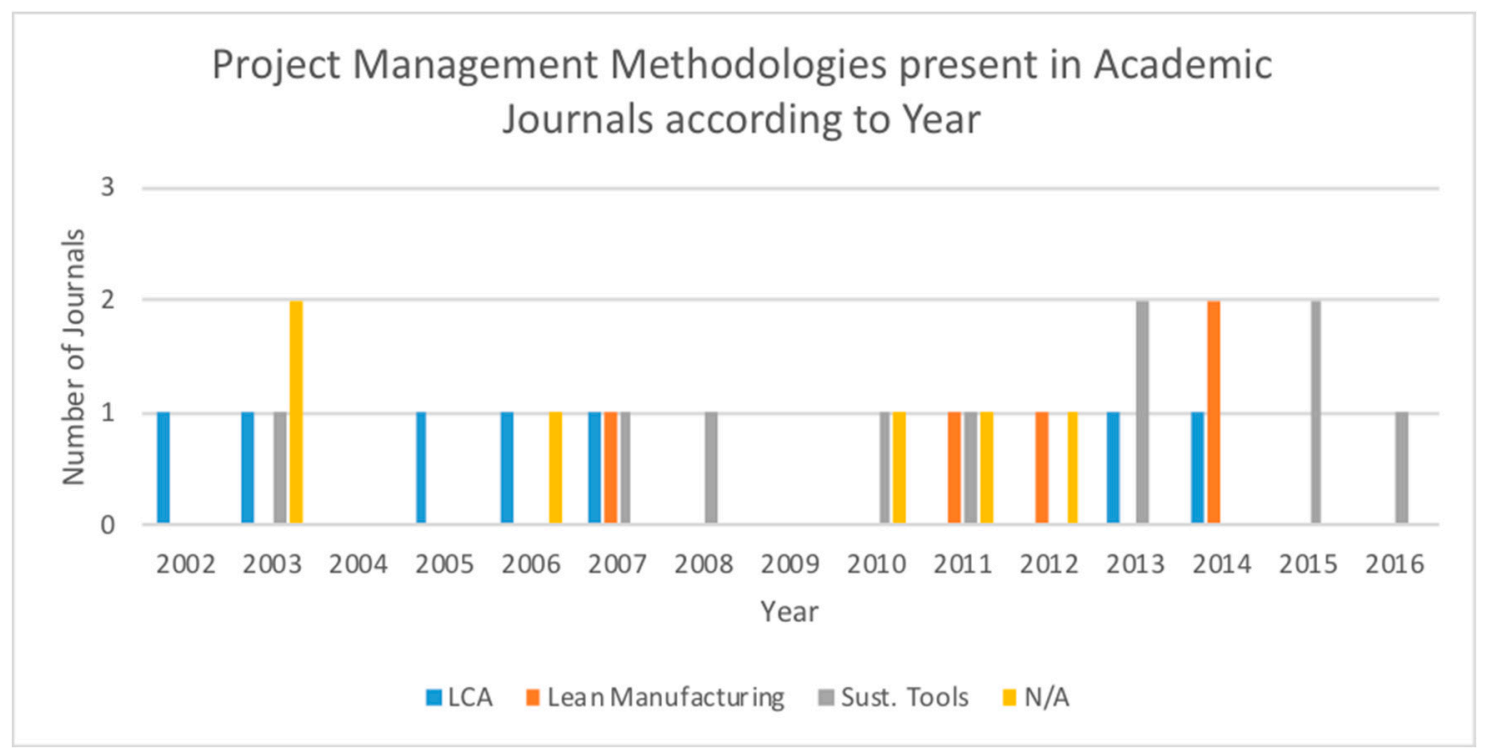

Figure 4. Constructs of sustainability.

This remains unanswered in the extant literature.

A Project Life Cycle is a linear process starting from Initiation, Planning, Monitoring \& Control, Execution, and Closing a project. Life Cycle Assessment (LCA) allows re-evaluation of business 
processes, activities or tasks at any point or stage in the Life Cycle. The majority of researchers used a methodology such as AHP and input/output analysis [9], SPSD [52], integration of manufacturing data, and sustainability indicators $[2,84]$ to assess the life cycle of a project or products. Some of the LCA had been empirically tested in actual project and reported positive results $[2,9,52,84]$. The challenge associated with LCA is the lack of evidenced-based data and information at present time $[84,86]$. The social sustainability criteria developed by [84] was flawed due to insufficient data on social criteria and practices. In a related observation, ref. [9] pointed out that their hierarchical method is convoluted and would not always result in producing the best decision.

It is important to note that LCA featured highly early in the 21st century but academic interest started to recline when Lean Manufacturing became a new research topic (Figure 4). Lean Manufacturing, focuses on minimizing the amount of waste during production process, thus registering positively on environmental management studies. Numerous authors had reputable work regarding a framework on Lean \& Green management $[53,61,87,90]$. Coincidentally, Ref. [87] also used sustainability indicators (Lean, Green and performance indicators) which is the same approach as the one in [84]. Only one author claimed that Lean Manufacturing had its shortcomings in their research where they had insufficient data [89].

Another related observation is that many studies around sustainability approaches and tools have not been considered as Project Management methodologies. For example, Green Supply Chain Management (GSCM) [66,72], eco-design, green purchasing [65,97], Voluntary Environmental Programs (VEP) [63], Environmental Management System [71] and Performance Management system [98]. There is however a connection here between tools and approaches to sustainable manufacturing and Project Management methodologies.

Given the many LCA versions and its versatility, this suggests that LCA has the ability to be integrated with any method depending on the manufacturing context. Different manufacturing companies have variable activities, and therefore require different Project Management methodological approaches. For example, a Project Manager working in a manufacturing company might consider using sustainable criteria indicators to monitor the effect of the machines to his project and environment. Meanwhile, a Manufacturing Engineer might practice more towards Lean Manufacturing to avoid material waste during its manufacturing processes. In other words, Lean Manufacturing can be a method integrated with the LCA. A supply chain manager that works for a manufacturer would carry out Green Supply Chain Management (GSCM) practices, suitable for supply chain activities.

From the literature it was noted that LCA is seen as the main integrative framework depending on the company's business strategy (Figure 5).

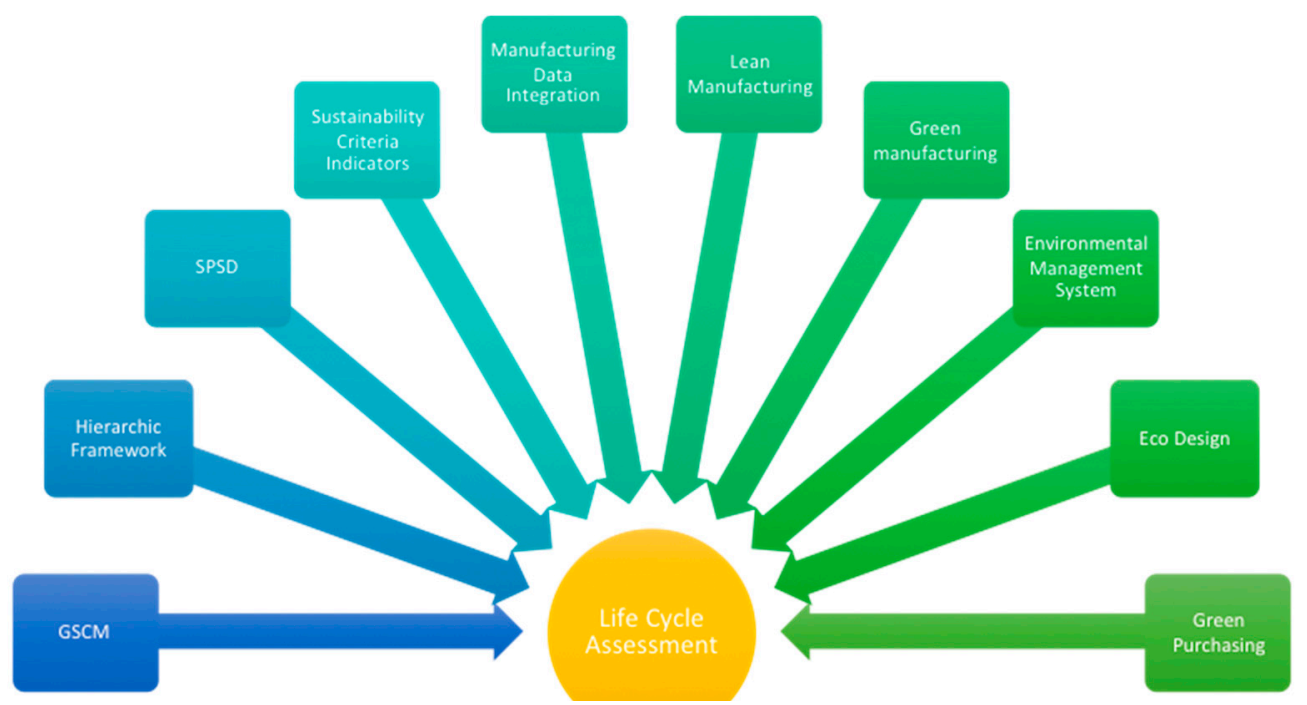

Figure 5. LCA as the main framework for Sustainable PM Methodology. 


\subsection{Incorporating Sustainability Constructs into Project Management Methodological Approaches (Research Question 3)}

The first part of the discussion addressed the sustainability constructs present in the manufacturing industry. Constructs such as coercive, mimetic, normative, internal and external pressures were all vital in achieving sustainability. The pressures themselves were unavoidable, but it can be minimized or used to gain advantage by incorporating them within Project Management Methodological approaches. Academic researchers have argued that current prevalent Project Management Methodologies addresses sustainability through environmental and social domains. This is embedded in the structures of LCA — that have sustainability indicators and Lean Manufacturing - that are focused on reducing waste.

What remains unclear from the literature is how to use the sustainability constructs to operationalize manufacturing project interventions within a formal project management methodological framework such as the PMI Project Management Book of Knowledge (PMBOK). A PMBOK "is an inclusive term that describes the sum of knowledge within the profession of project management" [99] (p. 2). The project management two knowledge areas from the PMBOK proposed in this work are: Stakeholder Management and Communication Management.

Project Stakeholder Management is a project knowledge area primarily concerned with identifying the people, clients, suppliers or organizations that could be impacted by the project. Governments, customers, social community, customers and industry institutions were some stakeholder examples [39,58]. A Project Manager needs to navigate this relational complexity of stakeholders' impact and conflicting sustainability expectations, by developing stakeholder engagement strategies to ensure stakeholders satisfaction in project decisions [13]. Collaboration with stakeholders is essential in order to obtain more sustainable solutions [10]. Turner's model (cited in [100]) presents the different roles in project management and the amount of responsibility that could be attributed to each towards the application of principles related to sustainability. The present research agrees with that of [100] in terms of the positive affect project managers can have on stakeholders' adherence to sustainability principles as well to other individuals in the organisation. Similarly, the engagement of stakeholders is considered to be one of the most crucial factors for sustainable practices [101]. Managing stakeholders in sustainable project processes is one of the key findings of the research conducted by [102].

A collaboration plan using available data sources such as internal company information and survey questionnaires to analyse stakeholders' perceptions, needs and interests was suggested by [39]. Some authors argue that stakeholders should be involved directly in decision-making as part of Corporate Social Responsibility (CSR) practices [9,10,62,84]. Manufacturers act as facilitators between the company, product designers and stakeholders [9]. The project last stage which is the control stage is more on controlling the whole stakeholder relationships in the project according to the planned parameters [13]. A Project Manager should know how to handle conflicts of interests and disagreement of opinion between stakeholders [48,66]. Furthermore, it is important to keep the stakeholders constantly interested in sustainability initiatives by incorporating them with the Project Management Methodology [98].

It is an easy assumption that stakeholder management depends on effective communication among stakeholders. Project Communications Management allows for strategic planning, creating, collection, processing, storage and retrieval of project information [99]. Communication is vital to improve efficiency and transparency of information flows in the project life cycle [87]. The importance of stakeholder communication was emphasised as well in [10] but the study also pointed out that the issue had not received proper attention according to standards. A plan for reporting mechanism to cater external stakeholders was suggested by [64], while the role of communication technologies such as social media to make a company more corporate credible was highlighted in [8]. Professional staff can also be connected by a cross-functional integration in environmental management systems [66]. By controlling the communication channels between stakeholders, it will generate further collaboration 
and communication between organisational departments [66]. The participation of stakeholders at either a national or international level is deemed necessary in sustainable product systems [102] and therefore effective communication is a key factor. Any gaps in the communication channels between stakeholders and the project team could potentially jeopardise sustainability decisions or collaborations [103]. Although the development of a communication mapping model for environmental management (CMEM) by [103] was based on six construction projects, other industries, including manufacturing, could greatly benefit from it.

In conclusion, it is evident that maintaining stakeholder satisfaction is essential to practice sustainable development strategies [64]. Therefore, a Project Manager needs to be competent in integrating those two areas of Project Management knowledge. This can be done by making all relevant stakeholders aware and understand of the sustainability practices conducted in the company through comprehensive communication and stakeholder management plans.

\section{Conclusions and Management Implications}

This research aims to extend our understanding on the implications of sustainability constructs upon project management approaches. Towards this, the three prevalent dialogues in the field of sustainability were considered relevant to the environmental and social aspects of the Triple Bottom Line. In being theory-led by utilizing Institutional Theory and working with literature review, it is proposed that organisational pressures are affecting sustainability efforts in industrial manufacturing project management. In the discussion, the authors have suggested that normative pressures are the main construct of sustainability, with coercive pressure having a constant presence in the recent literature. Nowadays, institutional pressures could result to negative consequences if not addressed. They can lead to dissatisfaction among stakeholders and potentially, disrupt a company's projects or business activities. The theoretical bodies of literature on Lean and Life Cycle Analysis in manufacturing project management were used to problematize that the various drivers of sustainability put forward that do not take into account the different organisational pressures fail to address institutional and systemic project management issues holistically. This study posits that the methodological approaches underpinning the project management knowledge areas of Stakeholder and Communications Management enable cohesive sustainable industrial results. The principle contribution is to offer a new conceptual perspective on integrating project management knowledge areas with Institutional Theory pressures for more sustainable project management methodologies. This study has important implications for managers. Even though numerous studies have evidenced and confirmed that environmentally responsible strategies impact positively on organisational financial performances and re-enforce their competitive advantage, sustainability poor performance continues to challenge organisations and their management. Much of the organisational focus has been on identifying and targeting economic performance factors at the first instance and less attention has been given to social and environmental aspects of sustainability. This is particularly apt in manufacturing environments, and thus this paper focusses on the nature-society imbalances in manufacturing practices that pose a threat to industrial stability. This research impacts the way managers embed sustainability practices within manufacturing projects by proposing a different operationalisation informed by institutional theory to ensure equity in stakeholders' relationships. Despite the valuable contribution to the body of sustainability literature there are a number of limitations in this research. The lack of empirical data meant that our chosen research methodology is dominated by a systematic literature review. In order to enhance academic rigor in the approach adopted, inclusion and exclusion criteria (Table 1) have been used to filter relevant studies. Notwithstanding, there is an inherent subjectivity when selecting the eligibility criteria of the studies underlying the research area. One could argue that further development of this research area would require more extensive qualitative research to further the theoretical understanding of organisational pressures as drivers in manufacturing projects. Future research should also examine under which project and organisational conditions 
typical Project Management Methodologies such as Agile, Scrum and Prince2, can incorporate elements of environmental and social sustainability.

Author Contributions: Following the conceptualisation stage, we have allocated tasks to each contributor, although the vast majority of the activities were conducted collectively: Conceptualization, F.M., R.M. and M.A.S.; Methodology, F.M., R.M., M.A.S., V.M. and Z.M.; Software, M.A.S.; Validation, F.M., R.M., M.A.S., V.M. and Z.M.; Formal Analysis, F.M., R.M. and M.A.S.; Investigation, F.M., R.M., M.A.S., V.M. and Z.M.; Resources, F.M., R.M., M.A.S., V.M. and Z.M.; Data Curation, M.A.S., V.M. and Z.M.; Writing-Original Draft Preparation, F.M., R.M., M.A.S., V.M. and Z.M.; Writing-Review \& Editing, F.M., R.M.; Visualization, F.M., R.M., M.A.S., V.M. and Z.M.; Supervision, F.M. and R.M.; Project Administration, F.M. and R.M.; Funding Acquisition, N/A.

Funding: This research received no external funding.

Conflicts of Interest: The authors declare no conflict of interest.

\section{References}

1. Brundtland, G.H. Our Common Future: Report of the World Commission on Environment and Development. Int. Aff. 1987, 64, 126. [CrossRef]

2. Labuschagne, C.; Brent, A.C. Sustainable Project Life Cycle Management: The need to integrate life cycles in the manufacturing sector. Int. J. Proj. Manag. 2005, 23, 159-168. [CrossRef]

3. Sillanpaa, M. A new deal for sustainable development in business: Taking the social dimension seriously. In Sustainable Measures: Evaluation and Reporting of Environmental and Social Performance; Bennett, M., James, P., Klinkers, L., Eds.; Routledge: New York, NY, USA, 2017; ISBN 978-1-874719-16-8.

4. Azapagic, A.; Perdan, S. Indicators of sustainable development for industry: A general framework. Process Saf. Environ. Prot. 2000, 78, 243-261. [CrossRef]

5. Ortiz, O.; Castells, F.; Sonnemann, G. Sustainability in the construction industry: A review of recent developments based on LCA. Constr. Build. Mater. 2009, 23, 28-39. [CrossRef]

6. Elkington, J. Cannibals with Forks: The Triple Bottom Line of 21st Century Business; New Society Publishers: Stony Creek, CT, USA, 1998.

7. Law, K.M.Y.; Gunasekaran, A. Sustainability development in high-tech manufacturing firms in Hong Kong: Motivators and readiness. Int. J. Prod. Econ. 2012, 137, 116-125. [CrossRef]

8. Gunasekaran, A.; Spalanzani, A. Sustainability of manufacturing and services: Investigations for research and applications. Int. J. Prod. Econ. 2012, 140, 35-47. [CrossRef]

9. Madu, C.N.; Kuei, C.; Madu, I.E. A hierarchic metric approach for integration of green issues in manufacturing: A paper recycling application. J. Environ. Manag. 2002, 64, 261-272. [CrossRef]

10. Jorgensen, T.H. Towards more sustainable management systems: Through life cycle management and integration. J. Clean. Prod. 2008, 16, 1071-1080. [CrossRef]

11. Rebitzer, G.; Ekvall, T.; Frischknecht, R.; Hunkeler, D.; Norris, G.; Rydberg, T.; Schmidt, W.P.; Suh, S.; Weidema, B.P.; Pennington, D.W. Life cycle assessment: Part 1: Framework, goal and scope definition, inventory analysis, and applications. Environ. Int. 2004, 30, 701-720. [CrossRef] [PubMed]

12. Hauschild, M.; Jeswiet, J.; Alting, L. From Life Cycle Assessment to Sustainable Production: Status and Perspectives. CIRP Ann. 2005, 54, 1-21. [CrossRef]

13. Project Management Institute. A Guide to the Project Management Body of Knowledge, 5th ed.; PMBOK ${ }^{\circledR}$ Guide; PMI: Newtown Square, PA, USA, 2013.

14. Bocchini, P.; Frangopol, D.; Ummenhofer, T.; Zinke, T. Resilience and Sustainability of Civil Infrastructure: Toward a Unified Approach. J. Infrastruct. Syst. 2014, 20, 1-16. [CrossRef]

15. Silvius, A.J.G.; Schipper, R.P.J. Sustainability in Project Management Competencies: Analyzing the Competence Gap of Project Managers. J. Hum. Resour. Sustain. Stud. 2014, 2, 40-58. [CrossRef]

16. Sánchez, M.A. Integrating sustainability issues into project management. J. Clean. Prod. 2014, 96, 319-330. [CrossRef]

17. Sarkis, J.; Meade, L.M.; Presley, A.R. Incorporating sustainability into contractor evaluation and team formation in the built environment. J. Clean. Prod. 2012, 31, 40-53. [CrossRef]

18. Chawla, V.K.; Chanda, A.K.; Angra, S.; Chawla, G.R. The sustainable project management: A review and future possibilities. Int. J. Proj. Manag. 2018, 3, 157-170. [CrossRef] 
19. Kerzner, H. Project Management: A Systems Approach to Planning, Scheduling, and Controlling, 12th ed.; John Wiley \& Sons: Hoboken, NJ, USA, 2017; ISBN 9781119165354.

20. Labuschagne, C.; Brent, A.C.; Claasen, S.J. Sustainable Project Life Cycle Management in the Process Industry. Corp. Soc. Responsib. Environ. Manag. 2005, 54, 38-54. [CrossRef]

21. Martens, M.L.; Carvalho, M.M. The challenge of introducing sustainability into project management function: Multiple-case studies. J. Clean. Prod. 2015, 117, 29-40. [CrossRef]

22. Elkington, J. Enter the Triple Bottom Line. In The Triple Bottom Line: Does It All Add Up? Henriques, A., Richardson, J., Eds.; Earthscan: London, UK, 2004; ISBN 1-84407-015-8.

23. Hall, T.J. The Triple Bottom Line: What Is It and How Does It Work? Indiana Bus. Rev. 2011, 86, 4-9.

24. Savitz, A.; Weber, K. The Triple Bottom Line; Jossey-Bass: San Francisco, CA, USA, 2006.

25. Talberth, J.; Cobb, C. The Genuine Progress Indicator; Redefining Progress: Oakland, CA, USA, 2007; pp. 1-33. Available online: http:/ / sustainable-economy.org/wp-content/uploads/GPI-2006-Final.pdf (accessed on 7 November 2017).

26. Shubham, C.P.; Murty, L.S. Organizational adoption of sustainable manufacturing practices in India: Integrating institutional theory and corporate environmental responsibility. Int. J. Sustain. Dev. World Ecol. 2018, 25, 23-34. [CrossRef]

27. Bruton, G.D.; Ahlstrom, D.; Li, H.L. Institutional Theory and Entrepreneurship: Where Are We Now and Where Do We Need to Move in the Future? Entrep. Theory Pract. 2010, 34, 421-440. [CrossRef]

28. Baumol, W.J.; Litan, R.E.; Schramm, C.J. Good Capitalism, Bad Capitalism, and the Economics of Growth and Prosperity; Yale University Press: New Haven, CT, USA, 2009.

29. Lai, K.; Wong, C.W.Y.; Cheng, T.C.E. Institutional isomorphism and the adoption of information technology for supply chain management. Comput. Ind. 2006, 57, 93-98. [CrossRef]

30. DiMaggio, P.J.; Powell, W.W. The iron cage revisited institutional isomorphism and collective rationality in organizational fields. In Economics Meets Sociology in Strategic Management (Advances in Strategic Management); Baum, J.A.C., Dobbin, F., Eds.; Emerald Group Publishing Limited: Bingley, UK, 2000; Volume 17, pp. 143-166, ISBN 978-0-76230-661-9.

31. Powell, W.W.; DiMaggio, P.J. (Eds.) The New Institutionalism in Organizational Analysis; University of Chicago Press: Chicago, IL, USA, 1991; ISBN 9780226677095.

32. Meyer, J.W.; Rowan, B. Institutionalized organizations: Formal structure as myth and ceremony. In The New Institutionalism in Organizational Analysis; Powell, W.W., DiMaggio, P.J., Eds.; University of Chicago Press: Chicago, IL, USA, 1991; pp. 41-62, ISBN 9780226677095.

33. Scott, W.R. Institutions and Organizations: Ideas and Interests, 3rd ed.; Sage Publications: Thousand Oaks, CA, USA, 2008; ISBN 978-1-4129-5090-9.

34. Toma, J.D.; Dubrow, G.; Hartley, M. The Uses of Institutional Culture: Strengthening Identification and Building Brand Equity in Higher Education. ASHE High. Educ. Rep. 2005, 31, 1-105.

35. Ball, A.; Craig, R. Using neo-institutionalism to advance social and environmental accounting. Crit. Perspect. Account. 2010, 21, 283-293. [CrossRef]

36. Rivera, J. An Institutional Pressures and Voluntary Environmental Behavior in Developing Countries: Evidence from the Costa Rican Hotel Industry. Soc. Nat. Resour. 2004, 17, 37-41. [CrossRef]

37. Lounsbury, M. Exploring the Institutional Tool Kit: The Rise of Recycling in the U.S. Solid Waste Field. Am. Behav. Sci. 1997, 40, 465-477. [CrossRef]

38. Glover, J.L.; Champion, D.; Daniels, K.J.; Dainty, A.J.D. An Institutional Theory perspective on sustainable practices across the dairy supply chain. Int. J. Prod. Econ. 2014, 152, 102-111. [CrossRef]

39. Delmas, M.; Toffel, M.W. Stakeholders and Environmental Management Practices An Institutional Framework. Bus. Strat. Environ. 2004, 13, 209-222. [CrossRef]

40. Morphew, C.C.; Huisman, J. Using Institutional Theory to Reframe Research on Academic Drift Using Institutional Theory to Reframe Research on. High. Educ. Eur. 2002, 27, 491-506. [CrossRef]

41. Morphew, C.C. Conceptualizing Change in the Institutional Diversity of U.S. Colleges and Universities. J. High. Educ. 2009, 80, 243-269. [CrossRef]

42. Kilbourne, W.E.; Beckmann, S.C.; Thelen, E. The role of the dominant social paradigm in environmental attitudes: A multinational examination. J. Bus. Res. 2002, 55, 193-204. [CrossRef]

43. Sarkis, J.; Zhu, Q.; Lai, K. An organizational theoretic review of green supply chain management literature. Int. J. Prod. Econ. 2011, 130, 1-15. [CrossRef] 
44. Campbell, J.L. Why would corporations behave in socially responsible ways? An institutional theory of corporate social responsibility. Acad. Manag. Rev. 2007, 32, 946-967. [CrossRef]

45. March, J.G.; Olsen, J.P. Rediscovering Institutions: The Organizational Basis of Politics; Free Press: New York, NY, USA, 1989.

46. Bansal, P. Evolving sustainably: A longitudinal study of corporate sustainable development. Strateg. Manag. J. 2005, 26, 197-218. [CrossRef]

47. Westphal, J.D.; Gulati, R.; Shortell, S.M. Customization or a Conformity? Institutional and Network Perspective on the Content and Consequences of TQM Adoption. Adm. Sci. Q. 1997, 42, 366-394. [CrossRef]

48. Keeble, J.J. Using Indicators to Measure Sustainability Performance at a Corporate and Project Level. J. Bus. Ethics 2003, 44, 149-158. [CrossRef]

49. Opoku, A.; Ahmed, V. Understanding sustainability: A view from intra-organizational leadership within UK construction organizations. Int. J. Archit. Eng. Constr. 2013, 2, 133-143. [CrossRef]

50. Lehtonen, M. The environmental-social interface of sustainable development: Capabilities, social capital, institutions. Ecol. Econ. 2004, 49, 199-214. [CrossRef]

51. Becker-Olsen, K.L.; Cudmore, B.A.; Hill, R.P. The impact of perceived corporate social responsibility on consumer behavior. J. Bus. Res. 2006, 59, 46-53. [CrossRef]

52. Maxwell, D.; Van Der Vorst, R. Developing sustainable products and services. J. Clean. Prod. 2003, 11, $883-895$. [CrossRef]

53. Hong, P.; Jungbae, R.J.; Rawski, G. Benchmarking sustainability practices: Evidence from manufacturing firms. Benchmarking Int. J. 2012, 19, 634-648. [CrossRef]

54. Closs, D.J.; Jacobs, M.A.; Swink, M.; Webb, G.S. Toward a theory of competencies for the management of product complexity: Six case studies. J. Oper. Manag. 2008, 26, 590-610. [CrossRef]

55. Marz, J.W.; Powers, T.L.; Queisser, T. Corporate and Individual Influences on Managers' Social Orientation. J. Bus. Ethics 2003, 46,1-11. [CrossRef]

56. Schrettle, S.; Secherrer-Rathje, M.; Friedli, T. Turning sustainability into action: Explaining firms' sustainability efforts and their impact on firm performance. Int. J. Prod. Econ. 2014, 147, 73-84. [CrossRef]

57. Hepworth, A.; Misopoulos, F.; Manthou, V.; Dyer, R.; Michaelides, R. Exploring ad-hoc portfolio management: Does it work, and is it the flexibility that supports project portfolio management? Procedia Comput. Sci. 2017, 121, 345-355. [CrossRef]

58. Tachizawa, E.M.; Gimenez, C.; Sierra, V. Green supply chain management approaches: Drivers and performance implications. Int. J. Oper. Prod. Manag. 2015, 35, 1546-1566. [CrossRef]

59. Anderson, S.; Daly, J.D.; Johnson, M. Why firms seek ISO 9000 certification: Regulatory compliance or competitive advantage? Prod. Oper. Manag. 1999, 8, 28-43. [CrossRef]

60. Cairns, J.J. Designing for nature and sustainability. Int. J. Sustain. Dev. World Ecol. 2006, 13, 77-81. [CrossRef]

61. Chiarini, A. Sustainable manufacturing-greening processes using specific Lean Production tools: An empirical observation from European motorcycle component manufacturers. J. Clean. Prod. 2014, 85, 226-233. [CrossRef]

62. Bey, N.; Hauschild, M.Z.; McAloone, T.C. Drivers and barriers for implementation of environmental strategies in manufacturing companies. CIRP Ann. 2013, 62, 43-46. [CrossRef]

63. Darnall, N.; Sides, S. Assessing the Performance of Voluntary Environmental Programs: Does Certification Matter? Policy Stud. J. 2008, 36, 95-117. [CrossRef]

64. Sangle, S. Empirical Analysis of Determinants of Adoption of Proactive Environmental Strategies in India. Bus. Strategy Environ. 2010, 19, 51-63. [CrossRef]

65. Zhu, Q.; Sarkis, J. Relationships between operational practices and performance among early adopters of green supply chain management practices in Chinese manufacturing enterprises. J. Oper. Manag. 2004, 22, 265-289. [CrossRef]

66. Wu, G.; Ding, J.; Chen, P. The effects of GSCM drivers and institutional pressures on GSCM practices in Taiwan's textile and apparel industry. Int. J. Prod. Econ. 2012, 135, 618-636. [CrossRef]

67. Hoffman, A.J. Institutional Evolution and Change: Environmentalism and the U.S. Chemical Industry. Acad. Manag. Rev. 1999, 42, 351-371.

68. Bingeman, K.; Berkes, F.; Gardner, J.S. Institutional responses to development pressures: Resilience of social-ecological systems in Himachal Pradesh, India. Int. J. Sustain. Dev. World Ecol. 2004, 11, 99-115. [CrossRef] 
69. Tate, W.L.; Dooley, K.J.; Ellram, L.M. Transaction Cost and Institutional Drivers of Supplier Adoption of Environmental Practices. J. Bus. Logist. 2011, 32, 6-16. [CrossRef]

70. King, A.A.; Lenox, M.J. Industry Self-Regulation without Sanctions: The Chemical Industry's Responsible Care Program. Acad. Manag. J. 2000, 43, 698-716.

71. Qi, G.Y.; Zeng, S.X.; Tam, C.M.; Yin, H.T.; Wu, J.F.; Dai, Z.H. Diffusion of ISO 14001 environmental management systems in China: Rethinking on stakeholders roles. J. Clean. Prod. 2011, 19, 1250-1256. [CrossRef]

72. Zhu, Q.; Geng, Y.; Fujita, T. Green supply chain management in leading manufacturers: Case studies in Japanese large companies. Manag. Res. Rev. 2010, 33, 380-392. [CrossRef]

73. Hettige, H.; Huq, M.; Pargal, S.; Wheeler, D. Determinants of Pollution Abatement in Developing Countries: Evidence from South and Southeast Asia. World Dev. 1996, 24, 1891-1904. [CrossRef]

74. Prakash, A.; Potoski, M. Racing to the Bottom? Trade, Environmental Governance, and ISO 14001. Am. J. Political Sci. 2006, 50, 350-364. [CrossRef]

75. Voss, C.; Ahlstrom, P.; Blackmon, K. Benchmarking and operational performance: Some empirical results. Int. J. Oper. Prod. Manag. 1997, 17, 1046-1058. [CrossRef]

76. Gladwin, T.N.; Kennelly, J.J.; Krause, T.S. Shifting paradigms for sustainable development: Implications for management theory and research. Acad. Manag. Rev. 1995, 20, 874-907. [CrossRef]

77. Labuschagne, C.; Brent, A.C. Sustainable project life cycle management: Aligning project management methodologies with the principles of sustainable development. In Proceedings of the PMSA International Conference, Johannesburg, South Africa, 10-12 May 2004; pp. 104-115.

78. Labuschagne, C.; Brent, A.C.; Van Erck, R.P.G. Assessing the sustainability performances of industries. J. Clean. Prod. 2005, 13, 373-385. [CrossRef]

79. Brent, A.C. A Proposed Lifecylce Impact Assessment Framework for South Africa from available environmental data. S. Afr. J. Sci. 2003, 99, 115-122.

80. Rosen, M.A.; Kishawy, H.A. Sustainable Manufacturing and Design: Concepts, Practices and Needs. Sustainability 2012, 4, 154-174. [CrossRef]

81. Dreyer, L.C.; Hauschild, M.; Schierbeck, J. A Framework for Social Life Cycle Impact Assessment. Int. J. Life Cycle Assess. 2006, 11, 88-97. [CrossRef]

82. Benoît, C.; Norris, G.; Valdivia, S.; Ciroth, A. The Guidelines for Social Life Cycle Assessment of products: Just in time! Int. J. Life Cycle Assess. 2010, 15, 156-163. [CrossRef]

83. Jørgensen, A.; Le Bocq, A.; Nazarkina, L.; Hauschild, M. Methodologies for Social Life Cycle Assessment. Int. J. Life Cycle Assess. 2008, 3, 96-103. [CrossRef]

84. Labuschagne, C.; Brent, A.C. Social indicators for sustainable project and technology life cycle management in the process industry. Int. J. Life Cycle Assess. 2006, 11, 3-15. [CrossRef]

85. Menichini, T.; Rosati, F. A Managerial Tool for Environmental Sustainability. APCBEE Procedia 2013, 5, 551-556. [CrossRef]

86. Mani, M.; Madan, J.; Lee, J.H.; Lyons, K.W.; Gupta, S.K. Sustainability characterisation for manufacturing processes. Int. J. Prod. Res. 2014, 52, 5895-5912. [CrossRef]

87. Verrier, B.; Rose, B.; Caillaud, E.; Remita, H. Combining organizational performance with sustainable development issues: The Lean and Green project benchmarking repository. J. Clean. Prod. 2014, 85, 83-93. [CrossRef]

88. Bergmiller, G.G.; Mccright, P.R. Parallel Models for Lean and Green Operations. In Proceedings of the Industrial Engineering Research Conference, Miami, FL, USA, 31 May-3 June 2009.

89. Rusinko, C.A. Green Manufacturing: An Evaluation of Environmentally Sustainable Manufacturing Practices and Their Impact on Competitive Outcomes. IEEE Trans. Eng. Manag. 2007, 54, 445-454. [CrossRef]

90. Yang, M.G.; Hong, P.; Modi, S.B. Impact of lean manufacturing and environmental management on business performance: An empirical study of manufacturing firms. Int. J. Prod. Econ. 2011, 129, 251-261. [CrossRef]

91. Bell, J. Doing Your Research Project: A Guide for First Time Researchers in Education and Social Science, 2nd ed.; Open University Press: Buckingham, UK, 1993.

92. Baumeister, R.F.; Leary, M.R. Writing narrative literature reviews. Rev. Gen. Psychol. 1997, 3, 311-320. [CrossRef] 
93. Siddaway, A. What Is a Systematic Literature Review and How Do I Do One? University of Stirling: Stirling, UK, 2014; Available online: https:/ / pdfs.semanticscholar.org/2214/2c9cb17b4baab118767e497c93806d741461. pdf (accessed on 14 August 2017).

94. Bloomberg, L.D.; Volpe, M. Completing Your Qualitative Dissertation: A Road Map from Beginning to End, 2nd ed.; Sage Publications: Thousand Oaks, CA, USA, 2012; ISBN 978-1-4522-0270-9.

95. Denyer, D.; Tranfield, D. Producing a systematic review. In The SAGE Handbook of Organizational Research Methods; Buchanan, D.A., Bryman, A., Eds.; Sage Publications Ltd.: London, UK, 2009; pp. 671-689.

96. Grant, M.J.; Booth, A. A typology of reviews: An analysis of 14 review types and associated methodologies. Health Inf. Libr. J. 2009, 26, 91-108. [CrossRef] [PubMed]

97. Zhu, Q.; Sarkis, J. The moderating effects of institutional pressures on emergent green supply chain practices and performance. Int. J. Prod. Res. 2007, 45, 37-41. [CrossRef]

98. Nappi, V.; Rozenfeld, H. The Incorporation of Sustainability Indicators into a Performance Measurement System. Procedia CIRP 2015, 26, 7-12. [CrossRef]

99. Project Management Institute. A Guide to the Project Management Body of Knowledge; PMBOK ${ }^{\circledR}$ Guide; PMI: Newtown Square, PA, USA, 2000. [CrossRef]

100. Goedknegt, D.; Silvius, G. The implementation of sustainability principles in project management. In Proceedings of the 26th IPMA World Congress, Crete, Greece, 29-31 October 2012.

101. Silvius, G.; Kampinga, M.; Paniagua, S.; Mooi, H. Considering sustainability in project management decision making: An investigation using Q-methodology. Int. J. Proj. Manag. 2017, 35, 1133-1150. [CrossRef]

102. Marcelino-Sadaba, S.; Gonzalez-Jaen, L.F.; Perez-Ezcurdia, A. Using project management as a way to sustainability. From a comprehensive review to a framework definition. J. Clean. Prod. 2015, 99, 1-16. [CrossRef]

103. Tam, V.W.; Shen, L.; Yau, R.M.; Tam, C. On using a communication-mapping model for environmental management CMEM to improve environmental performance in project development process. Build. Environ. 2006, 42, 3093-3107. [CrossRef] 